\title{
A Study of Political Economy in the Age of Austerity: How Incumbent Partisanship Affects Anti-Government Movements
}

\author{
Junpei Suzuki*1,2 \\ ${ }^{1}$ Waseda University ${ }^{\dagger}$ \\ ${ }^{2}$ Japan Society for the Promotion of Science ${ }^{\ddagger}$
}

January 26, 2021

\begin{abstract}
In the conventional literature of comparative political economy, fiscal austerity has been considered as a policy pursued typically by governments that adhere to conservative economic ideologies. In recent decades, however, especially after the Eurozone Crisis in 2009, not only right-wing governments but leftist and left-center coalition governments have also carried out austerity policies. While it is generally documented that fiscal austerity spurs citizens' grievances and leads to anti-government movements, whether and how the varying partisanship of the incumbent government affects the pattern of such movements is yet to be known. In this paper, I argue that austerity, when adopted by left-dominant governments, adds a "premium" to public grievances because, as the classic partisan theory posits (Hibbs 1977; Alesina 1987; Garrett and Lange 1989), citizens' prior beliefs about policy consequences are asymmetrical such that they have fewer expectations of austerity when the left-wing parties are in power. Accordingly, I hypothesize that austerity led by the leftist governments results in a higher likelihood of anti-government movements than that led by the right-dominant government. I support this hypothesis by analyzing panel data covering up to 37 developed countries between 1973 and 2015.
\end{abstract}

*A previous version of this paper was presented at the 2020 APSA Annual Meeting Exhibition, which was held virtually on. I thank Susumu Annaka, Antonio Benasaglio Berlucchi, Kentaro Hirose, Fumi Ikeda, Ikuo Kume, Masaru Kohno, Anna Luehrmann, Hideko Magara, Sofia Perez, Kohei Tabei, and Yukino Watanabe for helpful comments. This work is financially supported by JSPS KAKENHI Grant-in-Aid No. 19J14502. (ibn-la-ahad@asagi.waseda.jp)

$\dagger$ 1-6-1 Nishiwaseda, Shinjuku-ku, Tokyo, Japan.

$\ddagger 5-3-1$ Kohjimachi, Chiyoda-ku, Tokyo, Japan. 


\section{Introduction}

Fiscal austerity yields harsh impacts on the economic and social well-being of citizens by worsening their employment opportunities, welfare benefits, and financial situations generally, even damaging their physical and mental health conditions (Cummins 2018; Karanikolos et al. 2013; Stuckler and Basu 2013). Fiscal austerity is also said to undermine social capitals of communities (Jones et al. 2016) and to alter culture and practice in workplace (Walker, Annison, and Beckett 2019). Because of such manifold adverse consequences, austerity measures have often fueled furious responses from citizens in many countries, especially after the Eurozone Crises in 2009. In Greece, for example, citizens initiated a large-scale anti-austerity movement, called the "Indignant Citizens Movement," by starting nationwide demonstrations and strikes started on May 5, 2010 . Portuguese youth launched a movement called the "Geração à Rasca" ("desperate generation," in English), asking for improved working conditions $^{2}$. Inspired by this movement in the neighboring country, people in Spain also started the "15-M Movement" on May 15, 2011, as a protest against the labor market reforms. In the United Kingdom as well, a group of college students, called "UK Uncut," took the initiative of direct actions against public expenditure cuts and corporate practices of tax avoidance $^{3}$.

In the literature of comparative political economy, the recognition that fiscal austerity can be a major source of large-scale anti-government movements is hardly new (e.g., Haggard, Lafay, and Morrison 1995; Paldam 1993). What is noteworthy, however, is the fact that the frequency of such movements has been dramatically increasing in recent years, as shown in Figure $1^{4}$. According to this figure, which tracks the annual mean number of anti-government

1. BBC (2010) "Three dead as Greece protest turns violent". Retrieved from http://news.bbc.co.uk/2/hi/8661385.stm on September 12, 2020.

2. Schott, Ben (2011). "Geração à Rasca - NYTimes.com". The New York Times. Retrieved from https://schott.blogs.nytimes.com/2011/05/05/geracao-a-rasca/ on September 12, 2020.

3. The Guardian (2010) "High street stores hit in day of action over corporate tax avoidance" Retrieved from https://www.theguardian.com/uk/2010/dec/19/uk-uncut-tax-avoidance-protests on September $12,2020$.

4. The definition of anti-government movements and country coverage is described in the fourth section. 


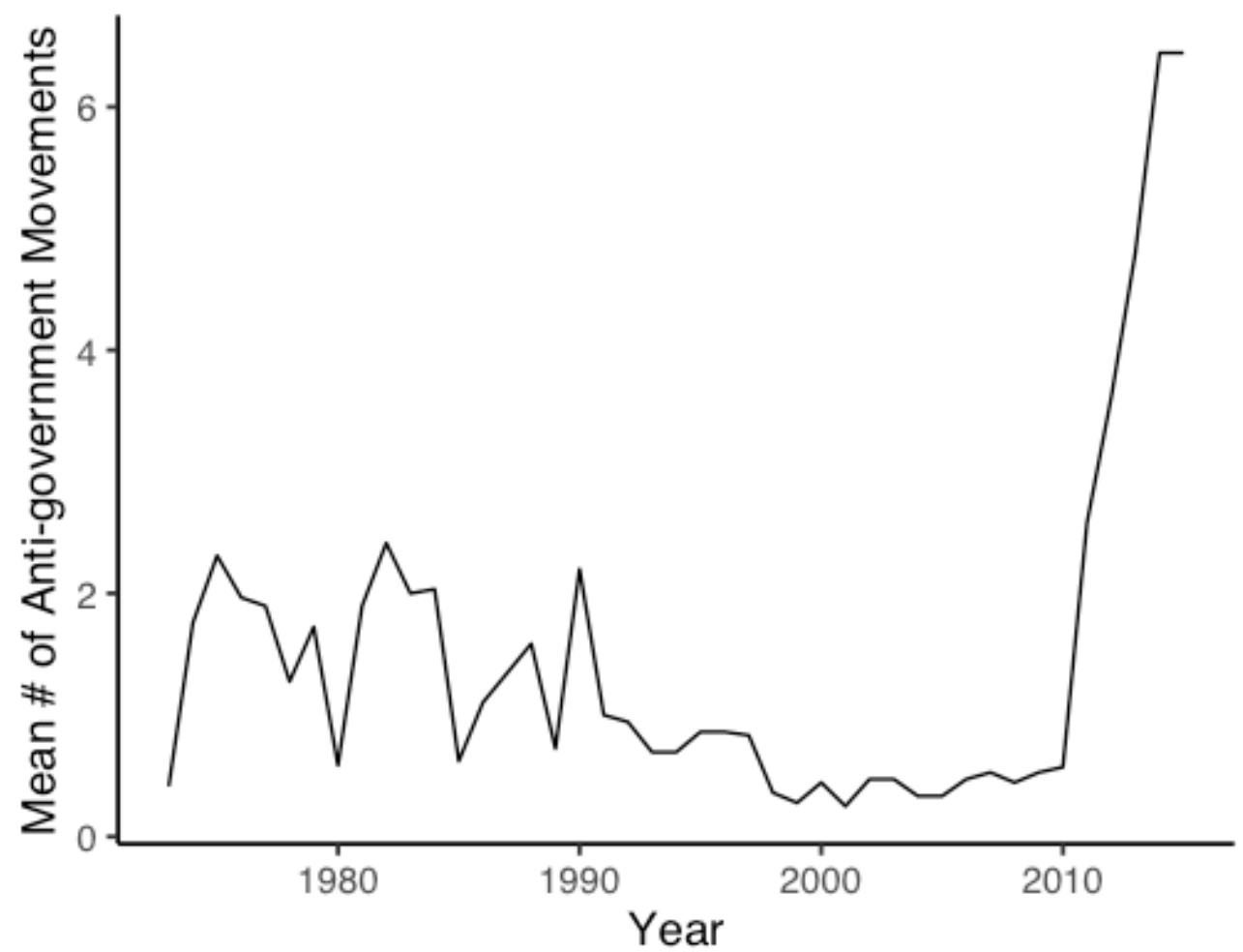

Note: For the definition of anti-government movements, please see the "Data, Variables, and Estimation" section.

Source: Banks and Wilson (2020)

Figure 1: Time-Series Trend of Mean Number of Anti-government Movements between 1972 and 2015

movements in 37 developed countries, the trend reveals a steady decline in the frequency of such movements during the 1990s and the early 2000s, but, after 2010, the trend seems to have reversed drastically.

Given the long, sustained interest in the role of political parties in comparative political economy, it is surprising that very little is known about whether and how the varying partisanship of incumbent government affects the pattern of these anti-austerity movements. The present paper seeks to fill this vacuum in the literature, by extending the classic partisan theory (Hibbs 1977; Alesina 1987; Garrett and Lange 1989) and conducting original empirical analysis. I begin by accepting the notion of the "convergence thesis" advanced by a group of economists and political scientists (Cusack 1999; Kurzer 1993; Scharpf 2000), observing 
that, in recent years, not only right-wing governments but leftist and left-center coalition governments have also carried out austerity policies. I argue, however, that the behavioral consequences of adopting austerity measures are not uniform, depending on the partisanship of the incumbent government. More specifically, I argue that austerity adds a "premium" to public grievances when adopted by left-dominant governments because, as the partisan theory posits, citizens' prior beliefs about policy consequences are asymmetrical such that they have less expectations of austerity when the leftist parties are in power. Especially those core supporters of left-wing parties are likely to feel disappointed and even betrayed, when they face their own favored government implementing austerity. Furthermore, because of such dismay, austerity adopted by left-dominant governments may have an effect of undermining the perceived utility of election as an opportunity for expressing interests, thus encouraging these supporters to retreat from electoral process (cf., Schäfer and Streeck 2013) and to opt for other forms of political participation, including anti-government movements(cf., Flesher Fominaya 2017). Accordingly, I hypothesize that austerity led by the left-dominant governments results in a higher likelihood of anti-government movements than that led by the government of the rightist parties. I test this hypothesis by analyzing panel data for 37 developed countries between 1973 and 2015, and present evidence in its support.

The remainder of this paper proceeds as follows. The next section reviews the extant literature and points out its problems in examining the mechanism of anti-austerity movements. The third section extends the conventional partisan theory and introduces a testable hypothesis. The fourth section describes the data and methodology for empirical analysis and present the result. The final section concludes with a summary of findings and discussion for further research.

\section{Previous Literature}

The "partisanship theory" in comparative political economy posits that political parties with different support base and ideological orientations have different preferences on economic 
policies. The seminal work in this tradition is Hibbs 1977, which argued and demonstrated that right-wing parties, supported by middle-income groups and businesses, put a higher priority on price stability and try to balance the government budget, while left-wing parties, supported by lower-income groups and ordinary employees, put a higher priority on employment by expanding government expenditure. A wide variety of empirical studies has since highlighted such left-right differences in economic policies and their consequence (e.g., Beckmann et al. 2017; Belke and Potrafke 2012; Boix 1998, 2000; Bräuninger 2005; Franzese 2002; Garrett 1995, 1998; Hibbs 1977; Korpi and Palme 1998, 2003; Potrafke 2009, 2017).

More recently, this well-established theoretical perspective has been challenged by the so-called "convergence thesis" advanced by some economists and political scientists, who point out that the left-right divide in economic policies has been fading away (e.g., Armingeon and Guthmann 2014; Boix 2000; Cusack 1999; Hines and Summers 2009; Hübscher 2015; Milner and Judkins 2004; Osterloh and Debus 2012; Persson and Tabellini 1992, 1994; Sakamoto 2008; Schäfer and Streeck 2013). Proponents of this thesis generally attribute the disappearance of left-right differences to the following three causes. First, they emphasize the impact of economic globalization, particularly that of capital flight. Taxation on capital should otherwise provide welfare states with a sufficient financial basis. Globalization, however, may undermine this revenue as it encourages capital to move beyond state borders (Schäfer and Streeck 2013; Scharpf 2000). Globalization also has an effect of deepening fiscal reliance on international financial market where actors prefer and often try to impose austerity measures upon national governments (e.g., Cusack 1999). Second, the proponents of the convergence thesis highlight changes in the labor market structure entailed by deindustrialization, a process defined as "the massive shift in employment from relatively dynamic manufacturing activities to generally less dynamic service provision" (Pierson 1998, 542). In a traditional industrial society, the labor market structure is said to be characterized by the existence of powerful trade unions as well as the practice of life-time and highly-paid employment, all of which once contributed to political fortune of left-wing parties. Dein- 
dustrialization has changed this structure into the unorganized, temporarily-employed, and low-wage model (Hemerijck 2018), which may in turn have eroded the electoral basis of left-wing parties (Kessler-Harris 2018; Kurzer 1991, 1993; Rueda 2005, 2006). Third, the convergence thesis underlines the impact of population aging, especially among advanced economies (Pierson 1996, 1998). Population aging may benefit left-wing parties electorally as it increases their supporters, i.e., the elderly who rely on broad range of welfare services. The increase of welfare recipients, however, imposes heavy burden on the governments' fiscal balance, which may prevent left-dominant governments to expand welfare expenditure. The aging therefore functions as an inhibitor, not a driver, of partisan politics.

Due to these difficulties, it is often pointed out that leftist governments have had no choice but to abandon their traditional policies and to opt for economic measures that were once typically pursued by right-wing parties in office. Indeed, the partisanship of the incumbent government seems to have lost its predictive power as determinant of economic policies, as illustrated by Figure 2. In this figure, a set of time-series trends of government fiscal balance are depicted for 37 developed countries between 1972 and 2015 based on the partisanship of the incumbent government. According to the figure, the national fiscal policy does not differ according to the partisanship of the incumbent government from the 1970s onward.

What are the socio-political consequences that such a partisan convergence brings about? To this question, in my view, the extant literature has not yet reached a scholarly consensus ${ }^{5}$. Indeed, the arguments and predictions thus far offered vary considerably.

As noted earlier, the previous generation of studies had investigated and indeed confirmed correlations between austerity adoption and anti-government movements (e.g., Haggard, Lafay, and Morrison 1995; Paldam 1993; Ponticelli and Voth 2019; Voth 2011), but their analyses did not pay attention to the question of partisanship per $\mathrm{se}^{6}$. Some recent studies

5. Arguably, the convergence thesis itself is not a consensus, as some scholars contend that left-right partisan politics remain salient. For such a view, see Garrett 1995, 1998 and Korpi and Palme 2003.

6. In this early literature, scholars used different words, other than austerity, to describe government policies. Paldam 1993, for example, used the term "adjustment measures," to denote not only fiscal austerity but also exchange rate control, anti-inflation programs, and domestic demand management. 


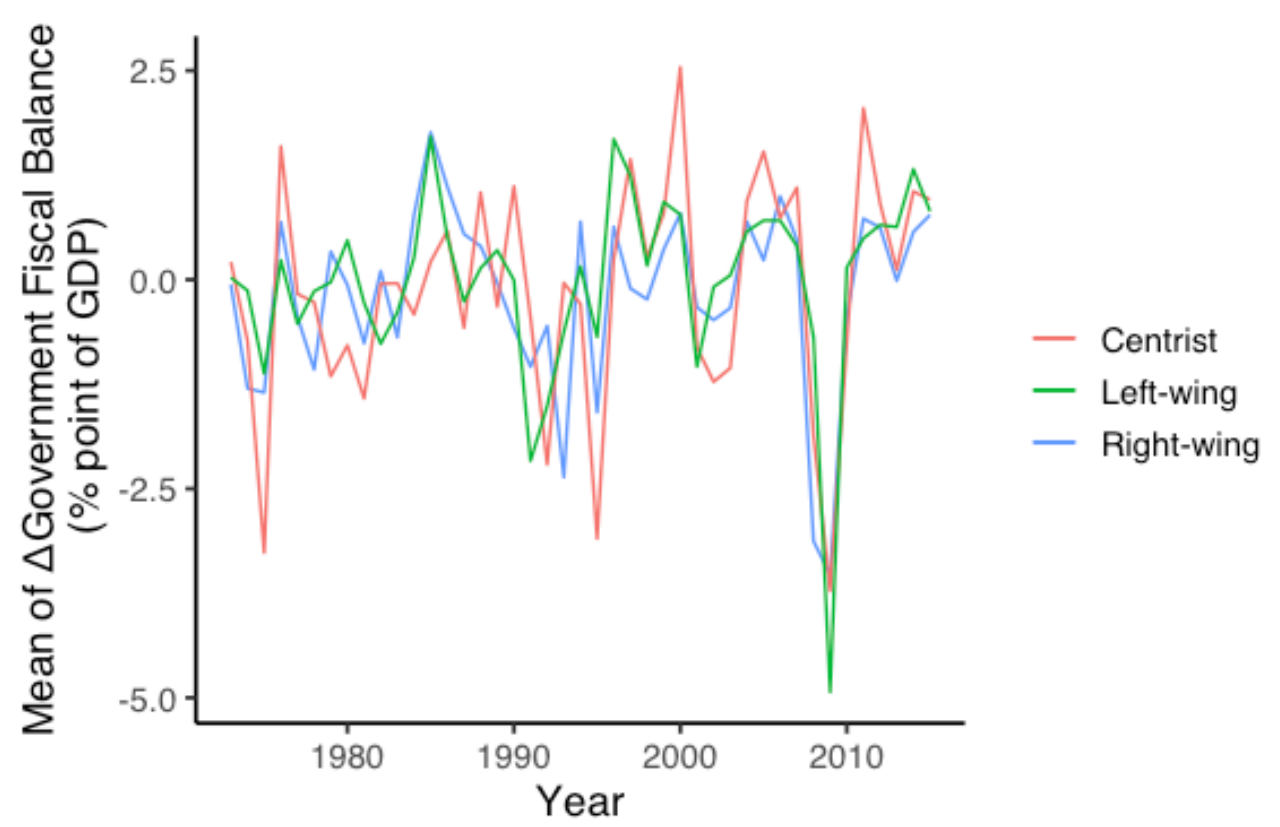

Note: For the definition of government fiscal balance and government partisanship, please see the "Data, Variables, and Estimation" section. Source: World Bank (2020)

Figure 2: Time-Series Trend of Mean of Annual Difference in Government Fiscal Balance by Government Partisanship between 1972 and 2015

have updated these earlier studies, based on the dataset that covers a longer period and larger number of countries, (e.g., Ponticelli and Voth 2019; Voth 2011), but they too generally fail to consider the partisan effect, nor do they elaborate on the impact that the disappearance of the left-right differences might incur.

In another strand of research, which does take the partisan convergence more seriously, claims and analyses have been offered that highlight a declining trend of voter turnout especially among Western countries. Schäfer and Streeck 2013, for example, posit that "many citizens now feel that electoral choices are limited and that turning out to vote is futile" (p.10) because whichever party is in office austerity is likely to be adopted as part of economic policy. Their prediction echoes with the argument offered in Armingeon and Guthmann 2014, which contend that austerity measures, often forcefully imposed upon by external actors like the IMF-EU-ECB Troika and the international financial market, led to decreased trust in national democracy. These recent studies thus suggest that the convergence has an 
effect of reducing citizens' perceived utility of election as a means of expressing their interests. However, while this line of studies shed light on some aspects of the convergence effect, in my view, their narrow focus on the electoral process fails to capture the significance of the dramatically increased anti-government movements. They fail, in particular, to address the possibility that the rise of such movements has been fostered precisely because of the reduced utility of elections.

In this context, Flesher Fominaya 2017 offers a novel perspective. In this detailed case study on southern Europe after the Global Crisis in 2007/2008, she explicitly cautions that austerity alone is insufficient for explaining the occurrence of anti-government movements. Like Schäfer and Streeck 2013, she acknowledges that convergence hinders citizens from voting, but she also emphasizes that retreating from electoral participation does not mean retreating from political participation entirely. Besides participating in elections, citizens have other options to convey their interests to the incumbent government, and these options are all the more attractive for those citizens who percieve the ordinary electional process is too ineffective to stop austerity. Now that left-wing parties adopt austerity, the emerged situation makes electoral participation unattractive for a larger subset of citizens. Here lies the seed for the recent growth of anti-government movements.

The discussion in Flesher Fominaya's case study can and should be generalized, because its insight is pointing to the need to reformulate the partisan theory in the age of austerity. It is true, and I am prepared to accept, that the convergence thesis seriously challenges the explanatory power of incumbent partisanship on economic policies. However, partisanship matters, not only as far as policy choices are concerned, but in the ultimate behavioral consequences in terms of voters' political participation. While the partisan convergence (in policy) may have caused the dramatic rise of anti-government movements, the pattern of such movements may not be uniform, depending on the partisanship of the incumbent government responsible for austerity. In the next section, I shall articulate this logic further and more formally, and intend to draw a testable hypothesis. 


\section{Partisan Theory in the Age of Austerity: "Leftist Premium" Hypoth- esis}

To understand whether and how the varying partisanship of the incumbent government affect the pattern of anti-government movements, let us revisit why citizens are motivated to participate in such movements when they face governments adopt policies of austerity. As noted earlier, austerity severely affect citizens' well-being, yielding negative impact on their employment opportunities, welfare benefits, and overall economic conditions. The worsened financial status of citizens feeds back to macroeconomic performances by, for example, reducing general consumptions and making firms and factories reluctant to expand investments. The deteriorated macroeconomic performance, in turn, worsens the financial status of citizens even further. As austerity causes such a vicious cycle, citizens start to nurse grievances against the incumbent government that has initiated austerity, thus taking to the street to express their grievances. This is a summary of the causal mechanism which links austerity and anti-government movements.

Though building upon this mechanism, I insist on the importance of taking into account the partisanship of the incumbent government responsible for austerity measures. More

specifically, I propose the "leftist premium hypothesis" which suggests that the level of public grievances is relatively higher (with the added "premium") when austerity policy is adopted by left-dominant governments. The grounds for this hypothesis are embedded in the original argument of the partisanship theory (Hibbs 1977; Alesina 1987; Garrett and Lange 1989), namely its basic tenet that citizens have asymmetrical prior briefs about the government behavior depending on whether the parties in power are left-wing or right-wing. Thus, for citizens, the austerity measures taken by the rightist government remains something in the realm of their expectations, though they certainly cause grievances. On the other hand, austerity policies adopted by leftist parties are likely to lead to a different scenario, as such a situation is in conflict with citizens' prior briefs about the behavior of these parties. This cognitive dissonance may be sensed most strongly by the traditional supporters of the leftist 
parties. Especially for those who are less-well-to-do and thus depend more heavily on public services, the prospect of retrenchment of these services is likely to feed disappointments and even the feeling of betrayal. It is for this reason I hypothesize that a "leftist premium" is added to the level of grievances, leading to a higher likelihood of anti-government movements, when the leftist governments adopt austerity policies.

This "premium," furthermore, is enhanced because, as noted by the previous studies like Schäfer and Streeck 2013, the convergence has the effect of decreasing the perceived utility of election as a process of expressing interests. Certainly, in the situation of rightwing austerity, angered citizens can still aim to vote the right-wing parties out of office, in accordance with their prior briefs that the left-wing parties, if elected, will retract austerity. When they face austerity initiated by left-wing austerity, however, citizens may no longer have confidence in the electoral process because there is no alternative party for which to vote in their hope of reversing austerity. Some of these citizens, as a result, may choose another route of voicing their interests, namely through anti-government movements ${ }^{7}$.

By extending this logic to the case where austerity is implemented by centrist governments, it is reasonable to predict that the likelihood of anti-government movements in such a situation is still higher than the case of rightist austerity. Generally, citizens do not expect centrist parties to adopt austerity. For that reason, it is possible to hypothesize that similar premium may be added to the level of public grievances against the centrist governments as well. However, the centrist premium is unlikely to be as sizable as the leftist premium, because the core supporters of the centrist parties still have an alternative, i.e. the leftist parties, to vote for in their hope of reversing austerity. Their sense of efficacy in relying on the electoral process is not entirely shattered and, at least in comparison with the case of leftist austerity, they are less motivated to take their grievances directly to the streets.

In sum, the partisanship of the incumbent government responsible for austerity affects

7. This mechanism can be paraphrased by the exit-voice framework of Hirschman 1970. The decreased utility of electoral participation means the disappearance of an exit option, which constitutes a solution to a collective action problem in expressing voices, namely initiating anti-government movements. 
the level of public grievances and the citizens' perceived utility of electoral participation, which in turn determine the likelihood of anti-government movements. My main hypothesis, and its corollary, can thus be stated:

Hypothesis: The likelihood that anti-government movements occur in the case where austerity is implemented by leftist governments is higher than that in the case where it is implemented by the rightist governments.

Corollary Hypothesis: The likelihood that anti-government movements occur in the case where austerity is implemented by centrist governments is higher than that in the case where it is implemented by the rightist governments, but not as high as in the case where it is implemented by the leftist governments.

\section{Data, Variables, and Estimation}

In this section, I test the above hypothesis based on unbalanced panel data, assembled from various sources, of 37 developed countries for the period between 1973 and $2015^{8}$. I first introduce main variables and then elaborate on the model and methods for estimation.

\section{Dependent Variables}

For my key dependent variable on the anti-government movements, I rely on Cross-National Time-Series data constructed by Banks and Wilson 2020, a dataset used in many previous studies on social unrest (e.g., Broz, Zhang, and Wang 2020; Ponticelli and Voth 2019; Voth 2011). This dataset records, based on articles published in the New York Times, a wide variety of domestic conflict events in a given country-year, which are categorize into eight episodes as defined by Tanter 1966: assassinations, general strikes, guerrilla warfare, major government crises, purges, riots, revolutions, and anti-government demonstrations. For the

8. The data covers Australia, Austria, Belgium, Bulgaria, Canada, Croatia, Cyprus, Czech Republic, Denmark, Estonia, Finland, France, Germany, Greece, Hungary, Iceland, Ireland, Israel, Italy, Japan, Latvia, Lithuania, Luxembourg, Malta, Netherlands, New Zealand, Norway, Poland, Portugal, Romania, Slovakia, Slovenia, Spain, Sweden, Switzerland, Turkey, and the United Kingdom. 


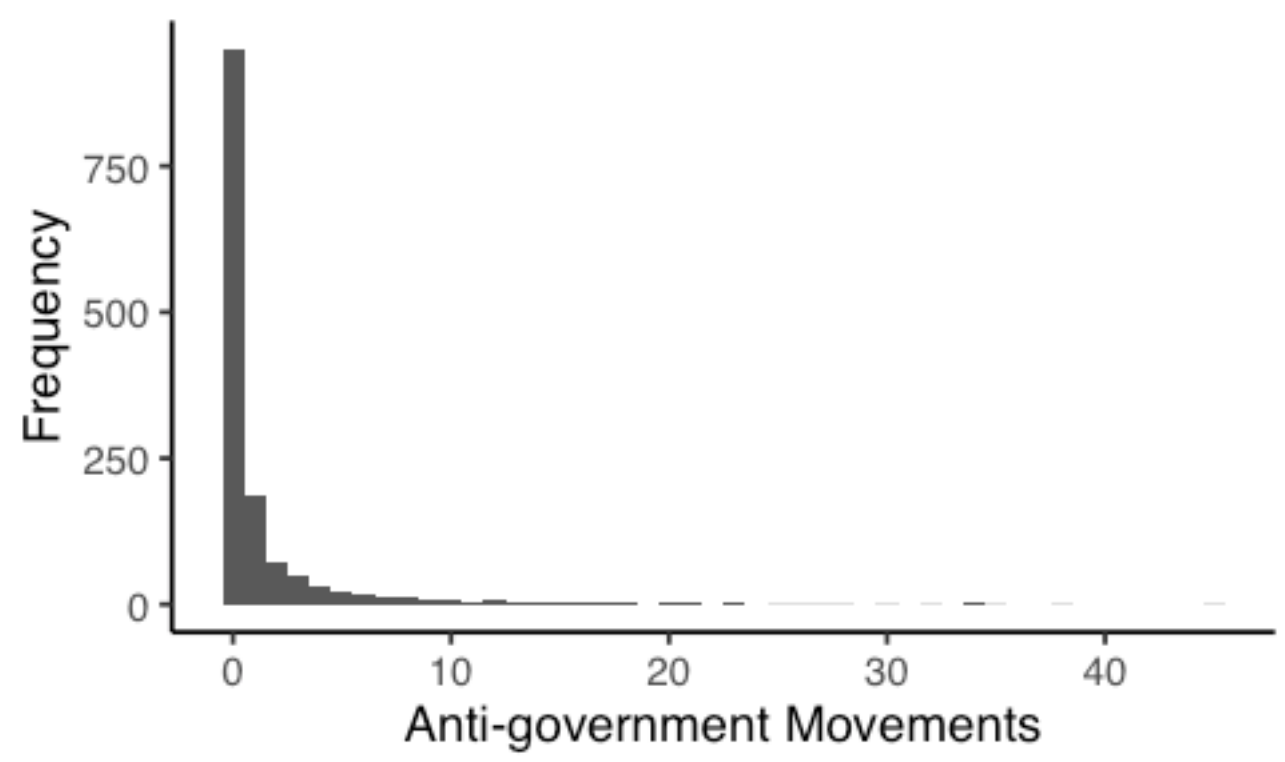

Source: Banks and Wilson (2020)

Figure 3: Distribution of Anti-government Movements

analysis below, I measure the frequency of anti-government movements by summing the frequency of anti-government demonstrations, riots and general strikes, disregarding others (guerilla warfare, major government crises, assassination, revolution, and purges) deemed irrelevant for the analysis of the developed countries. The total number of anti-government movements thus constructed is 2072 .

Of the three episodes included, the most frequent is anti-government demonstrations (54.5\%), and riots $(32.1 \%)$ and general strikes (13.4\%) follow in that order. Table A.1 reports summary statistics, and Figure 3 illustrates the variable distribution. On average, anti-government movements are rare events in the context of modern developed countries. Such rarity offers all the more reasons, in my view, to regard that the recent rise of antigovernment movements as representing a dramatic development worthy for a systematic investigation.

\section{Independent and Control Variables}

Fiscal Policy 
To measure tendency toward austerity requires a patent assessment of fiscal policy undertaken by different governments over time. In the previous studies, two different approaches have been used to measure government fiscal policy. The so-called narrative approach, taken by earlier studies like Paldam 1993 as well as more recent and sophisticated works like Muñoz, Anduiza, and Guillem 2014, determines the duration of austerity measures by citing historical documents. While this approach can exclude changes in non-political factors "correlated with other developments affecting output" (Guajardo, Leigh, and Pescatori 2014), the critical disadvantage is its dependence on the observer's arbitrary decisions on what events and incidents can be regarded as changes in the government's fiscal policy position. In what follows, I opt for the other established approach which utilizes standard economic indicators, as this approach is widely accepted in the literature as well (e.g., Alesina and Ardagna 2010; Alesina et al. 2002; Alesina and Perotti 1996; Giavazzi and Pagano 1990; Ponticelli and Voth 2019; Voth 2011).

More specifically, I use two variables to measure government fiscal policy. First, $\Delta$ Balance is the annual difference in government fiscal balance calculated as government revenue minus government expense, as a percentage of GDP. The data on government revenue and expense is from World Bank Open Data (World Bank 2020), and the detailed description is provided in Table A.1. The higher value of $\Delta$ Balance indicates the improvement of government fiscal balance and thus captures a tendency toward austerity. Second, I use annual difference of cyclically adjusted primary balance, $\triangle \mathrm{CAPB}$. Since this indicator excludes government borrowing, interest payments and cyclical variation in fiscal balance, it may be more suitable in measuring government fiscal policy without the influence of non-policy factors ${ }^{9}$. Its data source is the OECD Economic Outlook (OECD 2019). Like $\triangle$ Balance, the higher value of $\triangle \mathrm{CAPB}$ captures a stronger tendency toward austerity. The description of this variable is provided in Table A.1 as well.

Figure 4 depicts the distributions of these two variables. As shown, the values are clus-

9. CAPB is widely used by economists. See, among others, e.g., Alesina and Ardagna 2010; Alesina and Perotti 1996; Giavazzi and Pagano 1990. 

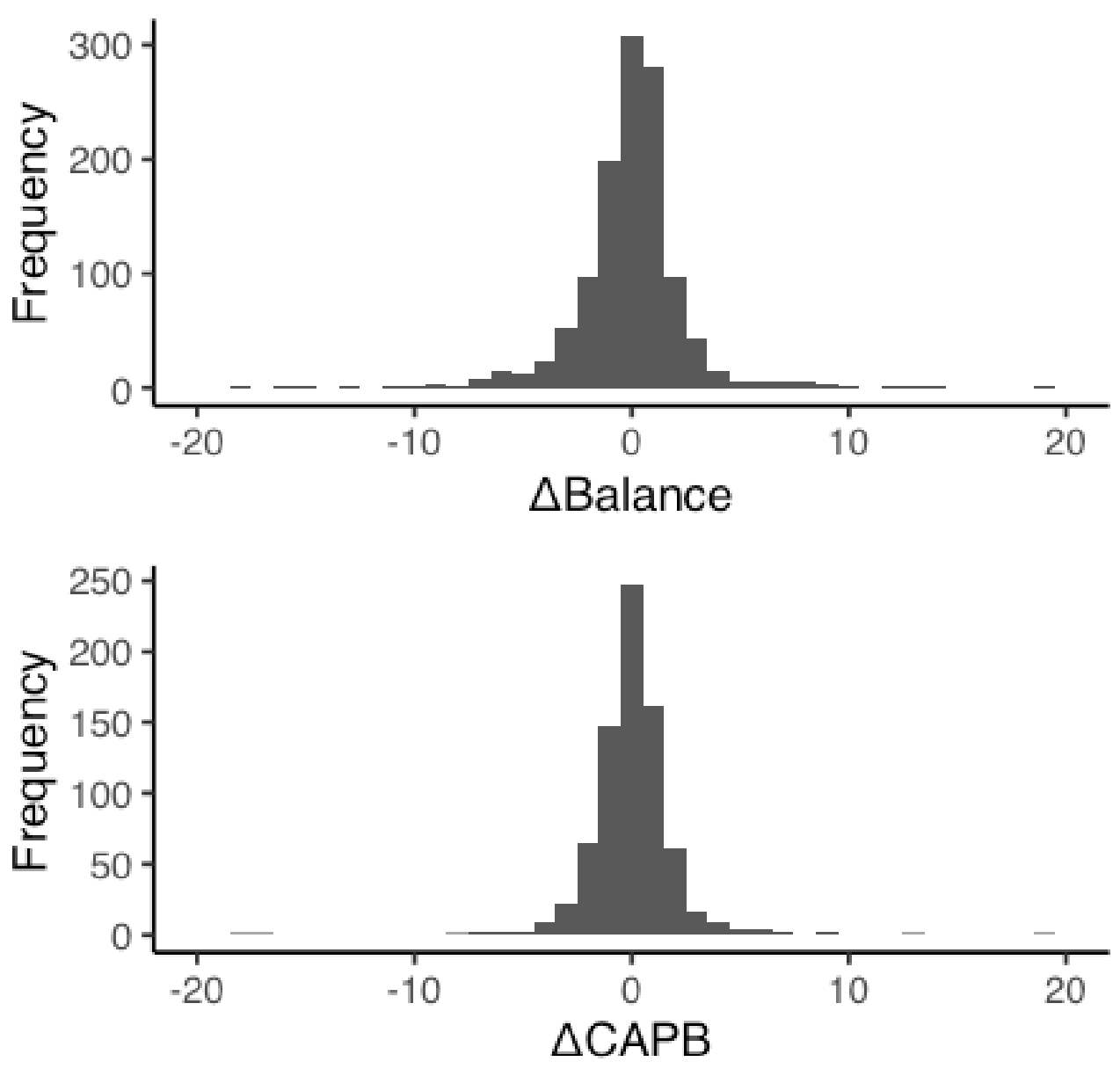

Source: World Bank (2020) and OECD (2019)

Figure 4: Distribution of Fiscal Variables

tered around zero, and over 10-percentage-point changes in the government fiscal policy rarely occur. However, the drastic deterioration of the government budget is observed in 2009, which reflects the explosion of the government deficit caused by the global financial crisis. The subsequent increase implies that many governments responded to the crisis by austerity measures.

\section{Partisanship}

For measuring partisanship, I use data on the orientation of incumbent governing parties in a given country-year from the ParlGov database (Döring and Manow 2019). This dataset records elections, political parties, and cabinets in established democracies, namely all EU 
and most OECD member countries, covering political parties that have one or more seats in the country's parliaments. Each party's position is rated, based on expert surveys, on a continuous scale between 1 and 10, in accordance with the left-right criteria suggested by several studies like Castles and Mair 1984. If this variable is close to 1, the party orientation is judged to be left, while if10 the orientation is judged to be right. I extract data only for those parties to which the prime ministers belong in a given country-year, assuming that prime ministers are the ultimate decision makers responsible for austerity measures, thus disregarding other informational details of each government, such as its majority-minority status or the precise composition of other parties in coalition if any.

For the analysis below, I use two variants of the partisanship measurement. First, I use the continuous 10 point-scale variable, as originally obtained from the dataset. This variable is made by negating the original variable from the ParlGov database, since my analysis focuses on the added effect of austerity when undertaken by left-dominant governments. Second, for the ease of interpreting the results, especially for the interaction terms, I also use the 3-point-scale partisan variable, converted from the continuous partisan variable. This is coded 0 if the government is recognized right-wing, 1 if centrist, or 2 if left-wing. The cutting points are set so that the sample is evenly broken down into three subsets. The mean of the "partisan" variable is close to 1, as shown in Table A.1, indicating that the conversion works appropriately.

Further adjustments are in order with regard to the timing of government change and policy initiation. Note in most countries under investigation, the government fiscal schedule is such that its budget plan is decided before an actual fiscal year starts. This might potentially create a troublesome measurement error. Suppose a positive change in budget balance is recorded in a given country-year and the government (prime minister's) partisanship in that country-year is coded based on its orientation as of April. If the actual inauguration of this government took place after April, the fiscal improvement should be attributed to the policy of, not this current government, but the previous government. In order to deal with this 
potential problem most effectively, I define partisanship based on ideological position of the government that holds office as of January 1st in a given year.

\section{Control Variables}

Here I consider and list some covariates that may affect the frequency of anti-government movements (see Table A.1 for the summary statistics and sources for these covariates). First, I control for the population scale, given that (more) frequent occurrence of anti-government movements may simply reflect a $\operatorname{larg}(\mathrm{er})$ national population. Specifically, I include the logarithm of the population, and this data is retrieved from Banks and Wilson 2020. Second, I control for general economic situations since worsening of economic conditions may encourage anti-government movements (Acemoglu and Robinson 2001; Burke and Leigh 2010; Kim 2014; Nordlinger 1977). Specifically, I take into consideration macroeconomic indicators including economic growth, unemployment, and inflation. Third, in light of the possibility that democratic institutions and mature civic culture may constitute necessary conditions for any social movements, I include Polity 2 variable that measures a given regime's degree of democracy (Marshall and Gurr 2020). Finally, because anti-government movements can be described as collective actions which can be facilitated by the prevalence of communication technology, I include as a control variable the logarithm of the number of phones as proxy to measure the diffusion of such technology (Ponticelli and Voth 2019).

\section{Model and Methods for Estimation}

As hypothesized in the previous section, I intend to examine whether policies of economic austerity adopted by left-dominant governments have stronger (positive) effects in facilitating anti-government movements than those adopted by rightist governments. For this, I estimate the following model:

Movements $_{i t}=\alpha+\beta_{1}$ Austerity $_{i t}+\beta_{2}$ Partisanship $_{i t}+\beta_{3}$ Austerity $\times$ Partisanship $_{i t}+\boldsymbol{\beta}^{\boldsymbol{T}} \boldsymbol{X}+\varepsilon_{i t}$

According to the previous literature, austerity increases the likelihood of anti-government 
movements, so $\beta_{1}$ should be greater than zero. As for $\beta_{2}$, my hypothesis remains agnostic as I suppose that the likelihood of citizens initiate anti-government movements does not depend directly on whether the incumbent government is leftist or rightist. Far more important to my hypothesis is $\beta_{3}$, namely the estimated coefficient for the interaction between government fiscal policy and incumbent partisanship. Since the government's leftist orientation is denoted with a greater value, $\beta_{3}$ is expected to be positive if my hypothesis is true.

Given that the dependent variable is a count variable that takes non-negative values and is positively skewed, as shown in Figure 3, OLS estimation is not appropriate. Thus, I use two sets of estimation methods, negative binomial and Poisson regression models, both of which are used widely in the analysis of count data in political science. As Poisson regression assumes that the mean of the dependent variables equals the variance, it is often pointed out that this method may not be suitable for analyzing over-dispersed data. In fact, the standard deviation of the dependent variable is 4.1 , which is greater than the mean, 1.5. For this reason, I use negative binomial as the main estimation model and employ Poisson estimation for robustness check.

\section{Empirical Findings}

Table 1 provides the result based on the negative binomial regression analyses with the 3-point-scale categorical partisan variable. The first three models (Models 1-3) include an annual difference in government fiscal balance ( $\Delta$ Balance) as a measurement of government fiscal policy measurement. As shown, $\Delta$ Balance is estimated consistently to have negative impacts on the dependent variable. Somewhat contrary to the previous scholarship this result suggests, that governments' efforts to improve their fiscal balance rather inhibit citizens from initiating anti-government movements. However, the estimated effects are not significant at conventional levels, and it is thus difficult to draw any conclusive inference on this point. Turning to the (categorical) partisan variables, they have consistently negative and significant effects. As the higher value indicates that the government is leftist, this result shows that 
anti-government movements are less likely to occur under left-dominant governments than under centrist and rightist governments.

The most important and novel finding of my empirical analysis concerns with the interaction between government fiscal balance and partisanship ( $\Delta$ Balance*Partisanship [Categorical]). The interaction is estimated consistently to have positive effects on the dependent variable, and the effect is significant in Models 2 and 3 which include a set of control variables. This result provides support for the hypothesis that left-dominant governments' austerity increases the likelihood of anti-government movements more than austerity initiated by centrist and rightist governments.

The next three models, Models 4-6, include an annual difference in cyclically-adjusted primary balance $(\triangle \mathrm{CAPB})$ to measure government fiscal policy. In contrast to $\Delta$ Balance, $\Delta \mathrm{CAPB}$ has consistently positive effects on the dependent variable, indicating governments' efforts to improve its fiscal balance may encourage citizens to initiate anti-government movements. This result is consistent with the previous scholarship. The interaction between $\triangle \mathrm{CAPB}$ and government partisanship is estimated to have positive effects on the dependent variable, and they are significant in Models 5 and 6 . This result supports my hypothesis as well.

For visualization, Figure 5 depicts the marginal effects of the fiscal policy variables on the dependent variables ${ }^{10}$. Note the effects are clearly correlated with the government partisanship (right, center, or left). According to Panel A, the marginal effect of $\Delta$ Balance on the dependent variable is close to zero when right-wing parties control governments. On the other hand, the marginal effects of the increase in government revenue conducted by the centrist and leftist governments exceed zero, and their $95 \%$ confidence intervals do not intersect the zero-horizontal line. Panel B also demonstrates the similar result that while rightist austerity has no effects on the likelihood of anti-government movements, centrist and leftist austerity has significantly positive effects. These results clearly supports my 10. Each panel in Figure 5 was drawn based on Models 3 and 6 in Table 1, respectively. 
Table 1: Result of Negative Binomial Regressions with Categorical Partisan Variable

\begin{tabular}{|c|c|c|c|c|c|c|}
\hline & \multicolumn{6}{|c|}{ Dependent variable: } \\
\hline & \multicolumn{6}{|c|}{ Anti-government Movements } \\
\hline & $(1)$ & $(2)$ & (3) & $(4)$ & $(5)$ & $(6)$ \\
\hline Lagged DV & $\begin{array}{c}0.075^{* * *} \\
(0.006)\end{array}$ & $\begin{array}{c}0.073^{* * *} \\
(0.006)\end{array}$ & $\begin{array}{c}0.065^{* * *} \\
(0.007)\end{array}$ & $\begin{array}{c}0.070^{* * *} \\
(0.007)\end{array}$ & $\begin{array}{c}0.066^{* * *} \\
(0.007)\end{array}$ & $\begin{array}{c}0.059^{* * *} \\
(0.007)\end{array}$ \\
\hline$\Delta$ Balance & $\begin{array}{l}-0.006 \\
(0.031)\end{array}$ & $\begin{array}{l}-0.020 \\
(0.033)\end{array}$ & $\begin{array}{l}-0.012 \\
(0.034)\end{array}$ & & & \\
\hline$\Delta$ Balance*Partisanship (Categorical) & $\begin{array}{c}0.039 \\
(0.025)\end{array}$ & $\begin{array}{l}0.071^{* *} \\
(0.033)\end{array}$ & $\begin{array}{l}0.066^{* *} \\
(0.033)\end{array}$ & & & \\
\hline$\triangle \mathrm{CAPB}$ & & & & $\begin{array}{c}0.042 \\
(0.036)\end{array}$ & $\begin{array}{c}0.031 \\
(0.039)\end{array}$ & $\begin{array}{c}0.046 \\
(0.041)\end{array}$ \\
\hline$\Delta$ CAPB*Partisanship (Categorical) & & & & $\begin{array}{c}0.044 \\
(0.036)\end{array}$ & $\begin{array}{l}0.065^{*} \\
(0.038)\end{array}$ & $\begin{array}{l}0.064^{*} \\
(0.039)\end{array}$ \\
\hline Partisanship (Categorical) & $\begin{array}{c}-0.157^{* *} \\
(0.070)\end{array}$ & $\begin{array}{c}-0.192^{* * *} \\
(0.072)\end{array}$ & $\begin{array}{c}-0.211^{* * *} \\
(0.072)\end{array}$ & $\begin{array}{c}-0.141^{*} \\
(0.079)\end{array}$ & $\begin{array}{c}-0.155^{* *} \\
(0.077)\end{array}$ & $\begin{array}{c}-0.169^{* *} \\
(0.075)\end{array}$ \\
\hline Log Population & & $\begin{array}{l}0.233^{* *} \\
(0.093)\end{array}$ & $\begin{array}{l}0.205^{* *} \\
(0.103)\end{array}$ & & $\begin{array}{c}0.329^{* * *} \\
(0.104)\end{array}$ & $\begin{array}{c}0.421^{* * *} \\
(0.121)\end{array}$ \\
\hline$\Delta$ Growth & & $\begin{array}{l}-0.007 \\
(0.019)\end{array}$ & $\begin{array}{l}-0.004 \\
(0.019)\end{array}$ & & $\begin{array}{c}0.013 \\
(0.025)\end{array}$ & $\begin{array}{c}0.013 \\
(0.024)\end{array}$ \\
\hline$\Delta$ Unemployment & & $\begin{array}{c}0.141^{* * *} \\
(0.047)\end{array}$ & $\begin{array}{c}0.150^{* * *} \\
(0.046)\end{array}$ & & $\begin{array}{l}0.093^{*} \\
(0.053)\end{array}$ & $\begin{array}{c}0.083 \\
(0.053)\end{array}$ \\
\hline$\Delta$ Inflation & & $\begin{array}{l}-0.005 \\
(0.008)\end{array}$ & $\begin{array}{l}-0.002 \\
(0.009)\end{array}$ & & $\begin{array}{c}-0.066^{*} \\
(0.034)\end{array}$ & $\begin{array}{c}-0.090^{* * *} \\
(0.035)\end{array}$ \\
\hline Polity 2 & & & $\begin{array}{c}-0.104^{*} \\
(0.061)\end{array}$ & & & $\begin{array}{c}-0.479^{* * *} \\
(0.122)\end{array}$ \\
\hline Log Phone & & & $\begin{array}{c}0.283^{* * *} \\
(0.092)\end{array}$ & & & $\begin{array}{c}0.359^{* * *} \\
(0.126)\end{array}$ \\
\hline Constant & $\begin{array}{c}-0.880^{* * *} \\
(0.118)\end{array}$ & $\begin{array}{c}-4.796^{* * *} \\
(1.592)\end{array}$ & $\begin{array}{c}-6.463^{* * *} \\
(2.116)\end{array}$ & $\begin{array}{c}-0.844^{* * *} \\
(0.141)\end{array}$ & $\begin{array}{c}-6.439^{* * *} \\
(1.780)\end{array}$ & $\begin{array}{c}-7.411^{* * *} \\
(2.672)\end{array}$ \\
\hline Country FE & Yes & Yes & Yes & Yes & Yes & Yes \\
\hline Year FE & Yes & Yes & Yes & Yes & Yes & Yes \\
\hline Log Likelihood & -1101.9 & -914.32 & -894.61 & -768.26 & -750.69 & -725.77 \\
\hline $\mathrm{N}$ & 1066 & 886 & 848 & 726 & 723 & 693 \\
\hline
\end{tabular}


A. $\Delta$ Balance

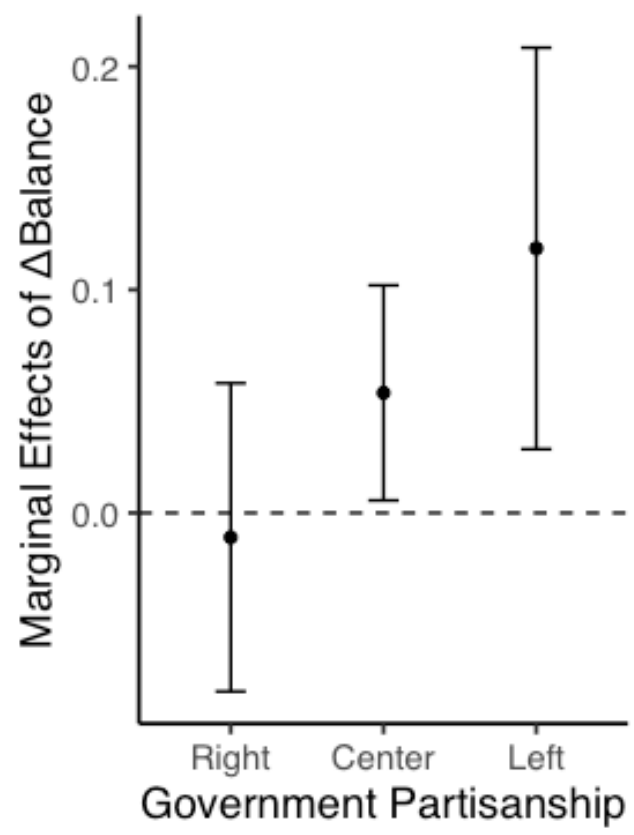

B. $\triangle \mathrm{CAPB}$

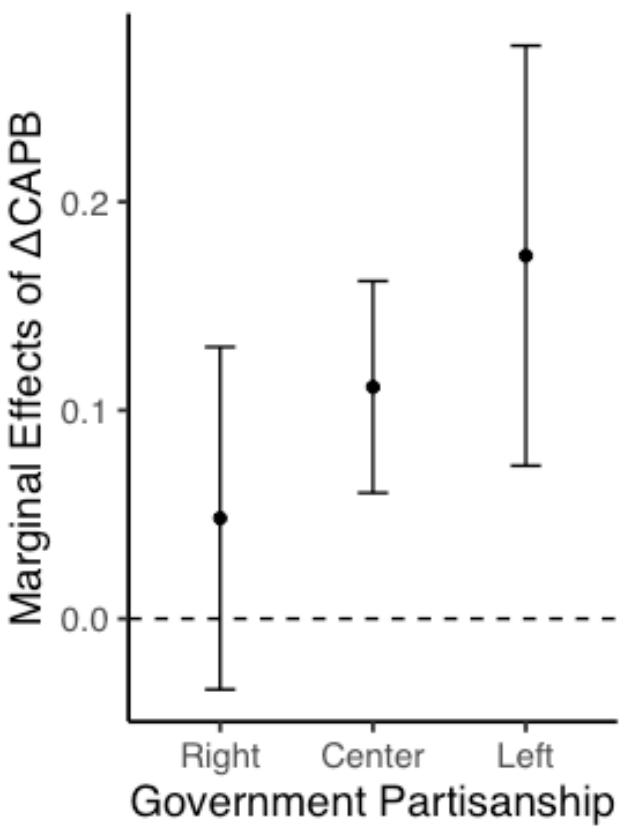

Figure 5: Marginal Effects of Fiscal Policy by Government Partisanship

main hypothesis.

On the other hand, however, neither Panel A nor B provide a clear support for my corollary hypothesis. Although the marginal effects for leftist governments seem slightly larger than those for centrist governments, their confidence intervals overlap each other. It implies, contrary to the initial prediction, that austerity initiated by centrist governments gives a "premium" to the public grievances and that its amount is sizable as the leftist premium.

Besides the negative binomial regressions with the categorical partisan variable, I run regressions with the continuous partisan variable. According to the results summarized in Table 2, coefficients of the original terms of the two fiscal variables (i.e., $\Delta$ Balance, and $\triangle \mathrm{CAPB})$ have consistently positive and significant effect on the dependent variable. It means that government fiscal surplus, or austerity, significantly increases the likelihood of anti-government movements, which is compatible with the findings in the previous literature. On the other hand, the interaction terms between each fiscal variable and government 
partisanship yield estimation results similar to Table 1: the interactions between $\Delta$ Balance and government partisanship, and between $\triangle \mathrm{CAPB}$ and government partisanship have consistently positive effects on the dependent variable. It implies that left-dominant governments' attempts to improve fiscal balance have stronger positive effects on the likelihood of anti-government movements, which supports the hypothesis.

Since the dependent variable used in the above results was constructed by aggregation, I have decomposed it into the three three episodes of anti-government movements, namely anti-government demonstrations, riots, and general strikes, and estimated separately based on negative binomial regression method. The results are shown in Table 3. Models 13 include $\Delta$ Balance as the measurement of government fiscal policy, whereas Models 4-6 include $\triangle \mathrm{CAPB}$. Across these six models, the interactions between government fiscal policy and partisanship have significant effects only for the models whose dependent variable are anti-government demonstrations: the hypothesis is not supported for violent movements nor strikes. This asymmetry of the disaggregated analysis is hardly surprising. In fact, the apparent absence of effects of left-wing austerity on violent movements is compatible with the discussion of Flesher Fominaya 2017, who emphasizes anti-austerity movement as "pro-democracy."

For the purpose of robustness check, I have also estimated the model with Poisson regressions. Their results are shown in Tables A.2 and A.3. The overall interpretation remains the same: austerity conducted by left-dominant governments has stronger effects on the likelihood of anti-government movements than austerity conducted by right-wing and centrist counterparts. In fact, the results of the Poisson regressions provide stronger support for the hypothesis, as the interactions between the two fiscal variables, and government partisanship have consistently significant effects on the dependent variable.

For another robustness check, I have also checked whether my argument is valid across periods. I divide the sample into three periods, 1972-2015 (Overall), 1980-2015, 1990-2015, and 2000-2015, and then estimated the negative binomial models separately for these periods. 
Table 2: Result of Negative Binomial Regressions with Continuous Partisan Variable

\begin{tabular}{|c|c|c|c|c|c|c|}
\hline & \multicolumn{6}{|c|}{ Dependent variable: } \\
\hline & \multicolumn{6}{|c|}{ Anti-government Movements } \\
\hline & $(1)$ & $(2)$ & $(3)$ & $(4)$ & $(5)$ & $(6)$ \\
\hline Lagged DV & $\begin{array}{c}0.075^{* * *} \\
(0.006)\end{array}$ & $\begin{array}{c}0.074^{* * *} \\
(0.006)\end{array}$ & $\begin{array}{c}0.066^{* * *} \\
(0.007)\end{array}$ & $\begin{array}{c}0.070^{* * *} \\
(0.007)\end{array}$ & $\begin{array}{c}0.067^{* * *} \\
(0.008)\end{array}$ & $\begin{array}{c}0.060^{* * *} \\
(0.008)\end{array}$ \\
\hline$\Delta$ Balance & $\begin{array}{l}0.152^{* *} \\
(0.071)\end{array}$ & $\begin{array}{c}0.298^{* * *} \\
(0.115)\end{array}$ & $\begin{array}{l}0.286^{* *} \\
(0.116)\end{array}$ & & & \\
\hline$\Delta$ Balance*Partisanship (Continuous) & $\begin{array}{c}0.021^{*} \\
(0.012)\end{array}$ & $\begin{array}{l}0.043^{* *} \\
(0.018)\end{array}$ & $\begin{array}{l}0.040^{* *} \\
(0.018)\end{array}$ & & & \\
\hline$\triangle \mathrm{CAPB}$ & & & & $\begin{array}{l}0.275^{* *} \\
(0.125)\end{array}$ & $\begin{array}{c}0.318^{* * *} \\
(0.123)\end{array}$ & $\begin{array}{c}0.323^{* * *} \\
(0.124)\end{array}$ \\
\hline$\Delta$ CAPB*Partisanship (Continuous) & & & & $\begin{array}{c}0.032 \\
(0.020)\end{array}$ & $\begin{array}{l}0.039^{* *} \\
(0.020)\end{array}$ & $\begin{array}{l}0.037^{*} \\
(0.020)\end{array}$ \\
\hline Partisanship (Continuous) & $\begin{array}{c}-0.087^{* * *} \\
(0.034)\end{array}$ & $\begin{array}{c}-0.109^{* * *} \\
(0.036)\end{array}$ & $\begin{array}{c}-0.123^{* * *} \\
(0.036)\end{array}$ & $\begin{array}{c}-0.089^{* *} \\
(0.040)\end{array}$ & $\begin{array}{c}-0.093^{* *} \\
(0.039)\end{array}$ & $\begin{array}{c}-0.096^{* *} \\
(0.038)\end{array}$ \\
\hline Log Population & & $\begin{array}{l}0.222^{* *} \\
(0.093)\end{array}$ & $\begin{array}{l}0.190^{*} \\
(0.103)\end{array}$ & & $\begin{array}{c}0.313^{* * *} \\
(0.105)\end{array}$ & $\begin{array}{c}0.397^{* * *} \\
(0.122)\end{array}$ \\
\hline$\Delta$ Growth & & $\begin{array}{l}-0.009 \\
(0.019)\end{array}$ & $\begin{array}{l}-0.007 \\
(0.019)\end{array}$ & & $\begin{array}{c}0.012 \\
(0.025)\end{array}$ & $\begin{array}{c}0.012 \\
(0.024)\end{array}$ \\
\hline$\Delta$ Unemployment & & $\begin{array}{c}0.142^{* * *} \\
(0.047)\end{array}$ & $\begin{array}{c}0.152^{* * *} \\
(0.046)\end{array}$ & & $\begin{array}{l}0.093^{*} \\
(0.052)\end{array}$ & $\begin{array}{c}0.082 \\
(0.052)\end{array}$ \\
\hline$\Delta$ Inflation & & $\begin{array}{l}-0.006 \\
(0.008)\end{array}$ & $\begin{array}{l}-0.003 \\
(0.009)\end{array}$ & & $\begin{array}{c}-0.067^{* *} \\
(0.033)\end{array}$ & $\begin{array}{c}-0.091^{* * *} \\
(0.034)\end{array}$ \\
\hline Polity 2 & & & $\begin{array}{l}-0.099 \\
(0.061)\end{array}$ & & & $\begin{array}{c}-0.472^{* * *} \\
(0.124)\end{array}$ \\
\hline Log Phone & & & $\begin{array}{c}0.292^{* * *} \\
(0.092)\end{array}$ & & & $\begin{array}{c}0.359^{* * *} \\
(0.126)\end{array}$ \\
\hline Constant & $\begin{array}{c}-1.531^{* * *} \\
(0.218)\end{array}$ & $\begin{array}{c}-5.421^{* * *} \\
(1.596)\end{array}$ & $\begin{array}{c}-7.264^{* * *} \\
(2.122)\end{array}$ & $\begin{array}{c}-1.486^{* * *} \\
(0.256)\end{array}$ & $\begin{array}{c}-6.845^{* * *} \\
(1.801)\end{array}$ & $\begin{array}{c}-7.781^{* * *} \\
(2.678)\end{array}$ \\
\hline Country FE & Yes & Yes & Yes & Yes & Yes & Yes \\
\hline Year FE & Yes & Yes & Yes & Yes & Yes & Yes \\
\hline Log Likelihood & -1100.87 & -913.21 & -893.18 & -767 & -749.71 & -725.01 \\
\hline $\mathrm{N}$ & 1066 & 886 & 848 & 726 & 723 & 693 \\
\hline
\end{tabular}


Table 3: Result of Negative Binomial Regression with the Dependent Variable Decomposed

\begin{tabular}{|c|c|c|c|c|c|c|}
\hline & \multicolumn{6}{|c|}{ Dependent variable: } \\
\hline & $\begin{array}{c}\text { Demonstration } \\
\text { (1) }\end{array}$ & $\begin{array}{c}\text { Riots } \\
(2)\end{array}$ & $\begin{array}{c}\text { General Strikes } \\
(3)\end{array}$ & $\begin{array}{c}\text { Demonstration } \\
(4) \\
\end{array}$ & $\begin{array}{c}\text { Riots } \\
(5)\end{array}$ & $\begin{array}{c}\text { General Strikes } \\
(6)\end{array}$ \\
\hline Lagged DV(domestic8) & $\begin{array}{c}0.127^{* * *} \\
(0.015)\end{array}$ & & & $\begin{array}{c}0.111^{* * *} \\
(0.017)\end{array}$ & & \\
\hline Lagged DV(domestic6) & & $\begin{array}{c}0.097^{* * *} \\
(0.018)\end{array}$ & & & $\begin{array}{c}0.093^{* * *} \\
(0.020)\end{array}$ & \\
\hline Lagged DV(domestic2) & & & $\begin{array}{c}0.198^{* * *} \\
(0.065)\end{array}$ & & & $\begin{array}{l}0.181^{* *} \\
(0.075)\end{array}$ \\
\hline$\Delta$ Balance & $\begin{array}{l}-0.022 \\
(0.037)\end{array}$ & $\begin{array}{c}0.051 \\
(0.059)\end{array}$ & $\begin{array}{c}0.049 \\
(0.068)\end{array}$ & & & \\
\hline$\Delta$ Balance*Partisanship (Categorical) & $\begin{array}{l}0.082^{* *} \\
(0.037)\end{array}$ & $\begin{array}{c}0.008 \\
(0.051)\end{array}$ & $\begin{array}{c}0.075 \\
(0.070)\end{array}$ & & & \\
\hline$\triangle \mathrm{CAPB}$ & & & & $\begin{array}{c}0.034 \\
(0.045)\end{array}$ & $\begin{array}{l}0.168^{* *} \\
(0.070)\end{array}$ & $\begin{array}{c}0.086 \\
(0.084)\end{array}$ \\
\hline$\triangle$ CAPB*Partisanship (Categorical) & & & & $\begin{array}{l}0.083^{*} \\
(0.043)\end{array}$ & $\begin{array}{l}-0.056 \\
(0.066)\end{array}$ & $\begin{array}{c}0.071 \\
(0.082)\end{array}$ \\
\hline Partisanship (Categorical) & $\begin{array}{l}-0.108 \\
(0.083)\end{array}$ & $\begin{array}{c}-0.380^{* * *} \\
(0.112)\end{array}$ & $\begin{array}{c}-0.511^{* * *} \\
(0.151)\end{array}$ & $\begin{array}{l}-0.070 \\
(0.088)\end{array}$ & $\begin{array}{c}-0.386^{* * *} \\
(0.120)\end{array}$ & $\begin{array}{c}-0.452^{* * *} \\
(0.166)\end{array}$ \\
\hline Log Population & $\begin{array}{c}0.206 \\
(0.126)\end{array}$ & $\begin{array}{c}0.233 \\
(0.194)\end{array}$ & $\begin{array}{l}-0.068 \\
(0.358)\end{array}$ & $\begin{array}{l}0.336^{* *} \\
(0.148)\end{array}$ & $\begin{array}{l}0.569^{* *} \\
(0.240)\end{array}$ & $\begin{array}{c}0.193 \\
(0.455)\end{array}$ \\
\hline$\Delta$ Growth & $\begin{array}{c}0.006 \\
(0.023)\end{array}$ & $\begin{array}{l}-0.028 \\
(0.028)\end{array}$ & $\begin{array}{l}-0.019 \\
(0.038)\end{array}$ & $\begin{array}{c}0.020 \\
(0.028)\end{array}$ & $\begin{array}{c}0.008 \\
(0.037)\end{array}$ & $\begin{array}{l}-0.018 \\
(0.051)\end{array}$ \\
\hline$\Delta$ Unemployment & $\begin{array}{l}0.136^{* *} \\
(0.054)\end{array}$ & $\begin{array}{c}0.215^{* * *} \\
(0.068)\end{array}$ & $\begin{array}{c}0.344^{* * *} \\
(0.085)\end{array}$ & $\begin{array}{c}0.057 \\
(0.062)\end{array}$ & $\begin{array}{l}0.149^{*} \\
(0.080)\end{array}$ & $\begin{array}{l}0.232^{* *} \\
(0.096)\end{array}$ \\
\hline$\Delta$ Inflation & $\begin{array}{l}-0.002 \\
(0.010)\end{array}$ & $\begin{array}{l}-0.016 \\
(0.013)\end{array}$ & $\begin{array}{c}0.015 \\
(0.017)\end{array}$ & $\begin{array}{c}-0.117^{* * *} \\
(0.040)\end{array}$ & $\begin{array}{l}-0.059 \\
(0.055)\end{array}$ & $\begin{array}{c}0.006 \\
(0.068)\end{array}$ \\
\hline Polity 2 & $\begin{array}{c}-0.151^{* *} \\
(0.066)\end{array}$ & $\begin{array}{l}-0.129 \\
(0.098)\end{array}$ & $\begin{array}{l}-0.009 \\
(0.167)\end{array}$ & $\begin{array}{c}-0.576^{* * *} \\
(0.162)\end{array}$ & $\begin{array}{c}-0.413^{* *} \\
(0.189)\end{array}$ & $\begin{array}{c}0.025 \\
(0.244)\end{array}$ \\
\hline Log Phone & $\begin{array}{c}0.297^{* * *} \\
(0.106)\end{array}$ & $\begin{array}{c}0.374^{* * *} \\
(0.138)\end{array}$ & $\begin{array}{c}-0.030 \\
(0.160)\end{array}$ & $\begin{array}{l}0.356^{* *} \\
(0.146)\end{array}$ & $\begin{array}{c}0.658^{* * *} \\
(0.201)\end{array}$ & $\begin{array}{c}0.093 \\
(0.210)\end{array}$ \\
\hline Constant & $\begin{array}{c}-6.313^{* *} \\
(2.533)\end{array}$ & $\begin{array}{c}-8.165^{* *} \\
(3.595)\end{array}$ & $\begin{array}{c}1.182 \\
(6.108)\end{array}$ & $\begin{array}{l}-5.151 \\
(3.254)\end{array}$ & $\begin{array}{c}-14.551^{* * *} \\
(4.480)\end{array}$ & $\begin{array}{l}-4.912 \\
(7.708)\end{array}$ \\
\hline Constant & $\begin{array}{c}-6.204^{* *} \\
(2.539)\end{array}$ & $\begin{array}{c}-7.785^{* *} \\
(3.606)\end{array}$ & $\begin{array}{c}1.693 \\
(6.114)\end{array}$ & $\begin{array}{l}-5.082 \\
(3.259)\end{array}$ & $\begin{array}{c}-14.165^{* * *} \\
(4.488)\end{array}$ & $\begin{array}{l}-4.459 \\
(7.714)\end{array}$ \\
\hline $\begin{array}{l}\text { Country FE } \\
\text { Year FE }\end{array}$ & $\begin{array}{l}\text { Yes } \\
\text { Yes }\end{array}$ & $\begin{array}{l}\text { Yes } \\
\text { Yes }\end{array}$ & $\begin{array}{l}\text { Yes } \\
\text { Yes }\end{array}$ & $\begin{array}{l}\text { Yes } \\
\text { Yes }\end{array}$ & $\begin{array}{l}\text { Yes } \\
\text { Yes }\end{array}$ & $\begin{array}{l}\text { Yes } \\
\text { Yes }\end{array}$ \\
\hline Log-Likelihood & -670.41 & -448.59 & -242.63 & -549.06 & -346.94 & -190.21 \\
\hline $\mathrm{N}$ & 848 & 848 & 848 & 693 & 693 & 693 \\
\hline
\end{tabular}


The results are displayed in Table A.4. The models that include $\Delta$ Balance (i.e., Models 1-4) show that the coefficients of the interaction between $\Delta$ Balance and partisanship are consistently positive and significant regardless of their period selection. This implies that the argument that left-wing austerity has stronger effects on the likelihood of anti-government movements than right-wing and centrist austerity is valid across different time periods. I note also that Models 5-8, which include $\triangle \mathrm{CAPB}$, provide only weaker validity to the argument: the interaction between $\triangle \mathrm{CAPB}$ and government partisanship is not significant in the models which cover more recent periods, i.e., 1990-2015 and 2000-2015. Nevertheless, the interaction remains significant in the models with longer periods (i.e., Overall and 1980-2015).

In sum, the empirical analysis reveals a set of important insights. First, fiscal austerity increases the likelihood of anti-government movements, as the previous literature has long suggested. Second and most importantly, the effect of austerity depends on the government's partisanship responsible for such measures. Austerity conducted by left-dominant governments has stronger effects on the likelihood of anti-government movements than austerity conducted by right-wing and centrist counterparts. Third, the conditional effects of austerity by government partisanship are observable across different time periods, at least after the 1970s - all of these buttresses the hypothesis.

\section{Conclusion}

So far I have investigated whether and how the varying partisanship of incumbent government affects the pattern of these anti-austerity movements. While accepting the notion of the "convergence thesis" literature, I extended the conventional partisan theory to link partisan convergence with behavioral consequences of citizens. Based on this expansion, I argued that partisan convergence on fiscal austerity encourages citizens to initiate anti-government movements by adding a "premium" to their grievances spurred by austerity and decreasing the perceived utility of electoral participation as a process of their interest. Then, I induced the observable hypothesis that anti-government movements are more likely to occur when 
left-dominant governments initiated the austerity than the right-dominant governments. I tested and supported this hypothesis by analyzing the panel data for 37 developed countries between 1973 and 2015 .

The main contribution of this paper to the scholarship is that it expanded the scope of the partisanship theory. The previous studies of both the conventional partisanship theory and the "convergence thesis" has been treating only economic policies (e.g., Cusack 1999, on fiscal policy) or macroeconomic performances (e.g., Hibbs 1977, on inflation and employment) as final consequences brought about by partisanship so far. This paper, however, presents the possibility and necessity that other consequences than policies or performances can and should be taken seriously in the context of the partisanship theory. Although it assumed that contents of implemented fiscal policy are not affected by partisanship of the incumbent government, the findings of this paper imply that partisanship makes difference if we turn our eyes to consequences coming after fiscal policy: anti-government movement.

This paper, however, relies on a couple of untested assumptions. The framework of this paper assumes that citizens who are disappointed by the effectiveness of electoral participation will automatically and immediately move to another form of political participation, anti-government movement. This assumption is the most doubtful of this paper because one cannot deny the possibility that citizens retreating from electoral participation retreat from another form of political participation as well. Besides, it is still unknown whether the amount of grievances that citizens facing austerity bear differs depending on the partisanship of the incumbent government. What is more, one can question even whether austerity causes citizens' grievances. As Paldam 1993 points out, deciding fiscal austerity may improve reputation of the politician as a reformer.

In order to address these problems, a future study needs to employ a micro-level and multilevel empirical strategy. Analyzing a micro-level data can assess whether and how the perceived utility in a respondent affects his/her experience of participating in antigovernment movements. If respondents who bear a higher degree of mistrust of electoral 
effectiveness, the first assumption of this paper is no longer baseless. A multilevel data is useful for assessing effects of fiscal policy, a macro-level variable, on the amount of grievances, a micro-level variable. In the multilevel analysis, it should be tested whether respondents in countries adopting austerity are angrier than those in countries not adopting austerity, and whether respondents facing left-dominant governments' austerity are angrier than those facing right-dominant governments' austerity.

A future study should improve the macro-level analysis this paper conducted as well. The empirical analysis of this paper does not consider the effects of coalition governments. Although both single-left-party governments and left-dominant right-allied governments are coded "leftist" in the empirical analysis, the assessment of partisanship of the latter case as a "leftist government" is exaggerated. Thus, a future study needs to code partisanship of the incumbent government taking into account of compositions of coalition governments. 


\section{References}

Acemoglu, Daron, and James Robinson. 2001. "Theory of Political Transitions." American Economic Review 91 (4): 938-963.

Alesina, Alberto. 1987. "Macroeconomic Policy in a Two-Party System as a Repeated Game." The Quarterly Journal of Economics 102 (3): 651-678. https:// doi.org/10.2307/ 1884222.

Alesina, Alberto, and Silvia Ardagna. 2010. "Large Changes in Fiscal Policy: Taxes versus Spending." Tax Policy and the Economy 24 (1): 35-68. https://doi.org/10.1086/649828.

Alesina, Alberto, Silvia Ardagna, Roberto Perotti, and Fabio Schiantarelli. 2002. "Fiscal Policy, Profists, and Investment." American Economic Review 92 (3): 571-589.

Alesina, Alberto, and Roberto Perotti. 1996. "Income distribution, political instability, and investment." European Economic Review 40 (6): 1203-1228.

Armingeon, Klaus, and Kai Guthmann. 2014. "Democracy in crisis? The declining support for national democracy in European countries, 2007-2011." European Journal of Political Research 53 (3): 423-442. https://doi.org/10.1111/1475-6765.12046.

Banks, Arthur S., and Kenneth A. Wilson. 2020. Cross-National Time-Series Data Archive. Dataset. https://www.cntsdata.com/.

Beckmann, Joscha, Esther Ademmer, Ansgar Belke, and Rainer Schweickert. 2017. "The political economy of the impossible trinity." European Journal of Political Economy 47:103-123. https://doi.org/10.1016/j.ejpoleco.2016.10.010.

Belke, Ansgar, and Niklas Potrafke. 2012. "Does government ideology matter in monetary policy? A panel data analysis for OECD countries." Journal of International Money and Finance 31 (5): 1126-1139. https://doi.org/10.1016/j.jimonfin.2011.12.014. 
Boix, Carles. 1998. Political parties, growth and equality: Conservative and social democratic economic strategies in the world economy. New York: Cambridge University Press.

— 2000. "Partisan Governments, the International Economy, and Macroeconomic Policies in Advanced Nations, 1960-93." World Politics 53 (1): 38-73. https://doi.org/10. 1017/s0043887100009370.

Bräuninger, Thomas. 2005. "A partisan model of government expenditure." Public Choice 125 (3-4): 409-429. https://doi.org/10.1007/s11127-005-3055-x.

Broz, J. Lawrence, Zhiwen Zhang, and Gaoyang Wang. 2020. "Explaining Foreign Support for China's Global Economic Leadership." International Organization 74 (3): 417-452. https://doi.org/10.1017/s0020818320000120.

Burke, Paul J., and Andrew Leigh. 2010. "Do Output Contractions Trigger Democratic Change?" American Economic Journal: Macroeconomics 2 (4): 124-157. https://doi. $\operatorname{org} / 10.1257 / \mathrm{mac} .2 .4 .124$.

Castles, Francis G, and Peter Mair. 1984. "Left-right political scales: Some 'expert'judgments." European Journal of Political Research 12 (1): 73-88.

Cummins, Ian. 2018. "The Impact of Austerity on Mental Health Service Provision: A UK Perspective." International Journal of Environmental Research and Public Health 15 (6). https://doi.org/10.3390/ijerph15061145.

Cusack, Thomas R. 1999. "Partisan Politics and Fiscal Policy." Comparative Political Studies 32 (4): $464-486$.

Döring, Holger, and Philip Manow. 2019. Parliaments and governments database (ParlGov): Information on parties, elections and cabinets in modern democracies. Development version. Dataset, January. http://www.parlgov.org/. 
Flesher Fominaya, Cristina. 2017. "European anti-austerity and pro-democracy protests in the wake of the global financial crisis." Social Movement Studies 16 (1): 1-20. https: //doi.org/10.1080/14742837.2016.1256193.

Franzese, Robert J. 2002. Macroeconomic Policies of Developed Democracies. Cambridge University Press.

Garrett, Geoffrey. 1995. "Capital mobility, trade, and the domestic politics of economic policy." International Organization 49 (4): 657-687.

1998. Partisan Politics in the Global Economy. New York: Cambridge University Press.

Garrett, Geoffrey, and Peter Lange. 1989. "Government Partisanship and Economic Performance: When and How does "Who Governs" Matter?" Journal of Politics 51 (3): 676-693.

Giavazzi, Francesco, and Marco Pagano. 1990. Can Severe Fiscal Contractions be Expansionary? Tales of Two Small European Countries. Report. National Bureau of Economic Research. https://doi.org/10.3386/w3372.

Guajardo, Jaime, Daniel Leigh, and Andrea Pescatori. 2014. "Expansionary Austerity? International Evidence." Journal of the European Economic Association 12 (4): 949-968. https://doi.org/10.1111/jeea.12083.

Haggard, Stephen, Jean-Dominique Lafay, and Christian Morrison. 1995. The political feasibility of adjustment in developing countries. OECD.

Hemerijck, Anton. 2018. "Social investment as a policy paradigm." Journal of European Public Policy 25 (6): 810-827. https://doi.org/10.1080/13501763.2017.1401111.

Hibbs, Douglas A. 1977. "Political parties and macroeconomic policy." American Political Science Review 71 (4): 1467-1487. 
Hines, James R., and Lawrence Summers. 2009. "How Globalization Affects Tax Design." Tax Policy and the Economy 23 (1): 123-158. https://doi.org/10.1086/597056.

Hirschman, Albert O. 1970. Exit, Voice, and Loyalty: Responses to Decline in Firms, Organizations, and States. Cambridge: Harvard University Press.

Hübscher, Evelyne. 2015. "The politics of fiscal consolidation revisited." Journal of Public Policy 36 (4): 573-601. https://doi.org/10.1017/s0143814x15000057.

Jones, Gerwyn, Richard Meegan, Patricia Kennett, and Jacqui Croft. 2016. "The uneven impact of austerity on the voluntary and community sector: A tale of two cities." Urban Studies 53 (10): 2064-2080. https://doi.org/10.1177/0042098015587240.

Karanikolos, Marina, Philipa Mladovsky, Jonathan Cylus, Sarah Thomson, Sanjay Basu, David Stuckler, Johan P. Mackenbach, and Martin McKee. 2013. "Financial crisis, austerity, and health in Europe." The Lancet 381 (9874): 1323-1331. https://doi.org/10. 1016/s0140-6736(13)60102-6.

Kessler-Harris, Alice. 2018. "Introduction: The Uneasy Promise of the Welfare State." In Democracy and the Welfare State: The Two Wests in the Age of Austerity, edited by Alice Kessler-Harris and Maurizio Vaudagna. New York: Columbia University Press.

Kim, Nam Kyu. 2014. "Revisiting Economic Shocks and Coups." Journal of Conflict Resolution 60 (1): 3-31. https://doi.org/10.1177/0022002713520531.

Korpi, Walter, and Joakim Palme. 1998. "The Paradox of Redistribution and Strategies of Equality: Welfare State Institutions, Inequality, and Poverty in the Western Countries." American Sociological Review 63 (5): 661. https://doi.org/10.2307/2657333.

. 2003. "New Politics and Class Politics in the Context of Austerity and Globalization: Welfare State Regress in 18 Countries, 1975-95." American Political Science Review 97 (03). https://doi.org/10.1017/s0003055403000789. 
Kurzer, Paulette. 1991. "Unemployment in Open Economies: The Impact of Trade, Finance and European Integration." Comparative Political Studies 24 (1): 3-30.

—. 1993. Business and Banking: Political Change and Economic Integration in Western Europe. Cornell studies in political economy. Ithaca: Cornell University Press.

Marshall, Monty G., and Ted Robert Gurr. 2020. Polity 5: Political Regime Characteristics and Transitions, 1800-2018. Center for Systemic Peace. Dataset.

Milner, Helen V, and Benjamin Judkins. 2004. "Partisanship, trade policy, and globalization: Is there a left-right divide on trade policy?" International Studies Quarterly 48 (1): 95119.

Muñoz, Jordi, Eva Anduiza, and Rico Guillem. 2014. "Empowering cuts? Austerity policies and political involvement in Spain." In How Welfare States Shape the Democratic Public: Policy Feedback, Participation, Voting, and Attitudes, edited by Steffan Kumlin and Isabelle Stadelmann-Steffen. Cheltenham: Edward Elgar.

Nordlinger, Eric A. 1977. Soldiers in Politics: Military Coups and Governments. Englewood Cliffs: Prentice Hall.

OECD. 2019. OECD Economic Outlook, Volume 2019 Issue 2. Report 106. Organization for Economic Co-operation and Development, November. https://doi.org/10.1787/ 9b89401b-en.

Osterloh, Steffen, and Marc Debus. 2012. "Partisan politics in corporate taxation." European Journal of Political Economy 28 (2): 192-207. https://doi.org/10.1016/j.ejpoleco.2011. 11.002 .

Paldam, Martin. 1993. The Socio-Political Reactions to Balance-of-Payments Adjustments in LDCs: A Study of Nine Cases from Latin America. Aarhus University. Mimeo. 
Persson, Torsten, and Guido Tabellini. 1992. "The Politics of 1992: Fiscal Policy and European Integration." Review of Economic Studies 59 (4): 689-701.

—. 1994. "Representative democracy and capital taxation." Journal of Public Economics 55 (1): 53-70.

Pierson, Paul. 1996. "The new politics of the welfare state." World Politics 48 (2): 143-179.

—. 1998. "Irresistible forces, immovable objects: post-industrial welfare states confront permanent austerity." Journal of European Public Policy 5 (4): 539-560. https://doi. org $/ 10.1080 / 13501769880000011$.

Ponticelli, Jacopo, and Hans-Joachim Voth. 2019. "Austerity and anarchy: Budget cuts and social unrest in Europe, 1919-2008." Journal of Comparative Economics, https://doi. $\operatorname{org} / 10.1016 /$ j.jce.2019.09.007.

Potrafke, Niklas. 2009. "Did globalization restrict partisan politics? An empirical evaluation of social expenditures in a panel of OECD countries." Public Choice 140 (1-2): 105-124. https://doi.org/10.1007/s11127-009-9414-2.

_ 2017. "Partisan politics: The empirical evidence from OECD panel studies." Journal of Comparative Economics 45 (4): 712-750. https://doi.org/10.1016/j.jce.2016.12.004.

Rueda, David. 2005. "Insider-Outsider Politics in Industrialized Democracies: The Challenge to Social Democratic Parties." American Political Science Review 99 (1): 61-74. https: //doi.org/10.1017/s000305540505149x.

—. 2006. "Social Democracy and Active Labour-Market Policies: Insiders, Outsiders and the Politics of Employment Promotion." British Journal of Political Science 36 (3): 385-406. https://doi.org/10.1017/s0007123406000214. 
Sakamoto, Takayuki. 2008. Economic Policy and Performance in Industrial democracies: Party Governments, Central Banks, and the Fiscal-monetary Policy Mix. London: Routledge.

Schäfer, Armin, and Wolfgang Streeck. 2013. "Introduction: Politics in the age of austerity." In Politics in the Age of Austerity, 1-25. Cambridge: Polity.

Scharpf, Fritz W. 2000. "The viability of advanced welfare states in the international economy: vulnerabilities and options." Journal of European Public Policy 7 (2): 190-228. https://doi.org/10.1080/135017600343160.

Stuckler, David, and Sanjay Basu. 2013. The Body Economic: Why Austerity Kills. New York: Basic Book.

Tanter, Raymond. 1966. "Dimensions of Conflict Behavior within and between Nations, 195860." The Journal of Conflict Resolution 10 (1): 41-64. www.jstor.org/stable/172710.

Voth, Hans-Joachim. 2011. "Tightening Tensions: Fiscal Policy and Civil Unrest in Eleven South American Countries, 1937-1995." In Fiscal Policy and Macroeconomic Performance, edited by Luis Felipe Céspedes and Jordi Galí. Santiago de Chile: Central Bank of Chile.

Walker, Samantha, Jill Annison, and Sharon Beckett. 2019. "Transforming Rehabilitation: The impact of austerity and privatisation on day-to-day cultures and working practices in 'probation'." Probation Journal 66 (1): 113-130. https://doi.org/10.1177/026455051 8820670.

World Bank. 2020. World Bank Open Data. Dataset, July 20. https://data.worldbank.org/. 


\section{A Online Supporting Materials (Not Intended for Print)}

This is the Online Appendix of "A Study of Political Economy in the Age of Austerity: How Incumbent Partisanship Affects Anti-Government Movements."

Table A.1: Summary Statistics

\begin{tabular}{|c|c|c|c|c|}
\hline Statistic & $\mathrm{N}$ & Mean & St. Dev. & Note \\
\hline \multicolumn{5}{|l|}{ Dependent Variables } \\
\hline Anti-government Movements & 1,415 & 1.5 & 4.1 & $\begin{array}{l}\text { domestic8 }+ \text { domestic6 }+ \text { domestic } 2 \\
\text { (see below). }\end{array}$ \\
\hline Anti-government Demonstrations & 1,415 & 0.8 & 2.3 & $\begin{array}{l}\text { domestic8: Any peaceful public gath- } \\
\text { ering of at least } 100 \text { people for the pri- } \\
\text { mary purpose of displaying or voicing } \\
\text { their opposition to government poli- } \\
\text { cies or authority, excluding demonstra- } \\
\text { tions of a distinctly anti-foreign nature } \\
\text { (Banks \& Wilson, 2020). }\end{array}$ \\
\hline Riots & 1,415 & 0.5 & 1.7 & $\begin{array}{l}\text { domestic9: Any violent demonstration } \\
\text { or clash of more than } 100 \text { citizens in- } \\
\text { volving the use of physical force (Banks } \\
\text { \& Wilson, 2020). }\end{array}$ \\
\hline General Strikes & 1,415 & 0.2 & 0.7 & $\begin{array}{l}\text { domestic2: Any strike of } 1,000 \text { or more } \\
\text { industrial or service workers that in- } \\
\text { volves more than one employer and } \\
\text { that is aimed at national government } \\
\text { policies or authority (Banks \& Wilson, } \\
2020 \text { ). }\end{array}$ \\
\hline
\end{tabular}

Independent Variables: Fiscal Policy

\section{$\Delta$ Balance}

$\triangle \mathrm{CAPB}$

$\Delta$ Revenue

$\Delta$ Expense

Independent Variables: Partisanship

Partisanship (Categorical)

Partisanship (Continuous)

$1,276 \quad-5.6$

1.7

Control Variables

Log Population

$\Delta$ Growth

$\Delta$ Unemployment

$\Delta$ Inflation

Polity 2

Log Phone

$\begin{array}{ccc}1,195 & -0.05 & 2.6 \\ 763 & 0.02 & 2.1 \\ & & \\ 1,209 & 0.2 & 3.1 \\ 1,206 & 0.2 & 3.5\end{array}$

$\begin{array}{lll}1,276 & 1.0 & 0.8\end{array}$

categorical variable recoded from left_right (Döring \& Manow, 2019). $1=$ righit, $2=$ center, and $3=$ left.

left_right: 1 to 10 expert survey-based indicator of ideology of prime minister's party as of July 1st in the year (Döring \& Manow, 2019).

\begin{tabular}{|c|c|c|}
\hline 15.9 & 1.5 & $\begin{array}{l}\text { Natural logarithm of pop1 } 101000 \\
\text { (Banks \& Wilson, 2020). }\end{array}$ \\
\hline-0.03 & 3.4 & $\begin{array}{l}\text { Annual difference in gross domestic } \\
\text { product, volume, growth (OECD, 2020). }\end{array}$ \\
\hline 0.1 & 1.2 & $\begin{array}{l}\text { Annual difference in unemployment } \\
\text { rate (OECD, 2020). }\end{array}$ \\
\hline-1.8 & 89.6 & $\begin{array}{l}\text { Annual difference in inflation, con- } \\
\text { sumer price (OECD, 2020). }\end{array}$ \\
\hline 8.5 & 4.0 & Marshall and Gurr (2020). \\
\hline 11.0 & 0.9 & $\begin{array}{l}\text { Natural logarithm of phone } 6 \text { (Banks \& } \\
\text { Wilson, 2020). }\end{array}$ \\
\hline
\end{tabular}


Table A.2: Result of Poisson Regressions with Categorical Partisan Variable

\begin{tabular}{|c|c|c|c|c|c|c|}
\hline & \multicolumn{6}{|c|}{ Dependent variable: } \\
\hline & \multicolumn{6}{|c|}{ Anti-government Movements } \\
\hline & $(1)$ & $(2)$ & $(3)$ & $(4)$ & $(5)$ & $(6)$ \\
\hline Lagged DV & $\begin{array}{c}0.072^{* * *} \\
(0.003)\end{array}$ & $\begin{array}{c}0.059^{* * *} \\
(0.003)\end{array}$ & $\begin{array}{c}0.061^{* * *} \\
(0.004)\end{array}$ & $\begin{array}{c}0.065^{* * *} \\
(0.003)\end{array}$ & $\begin{array}{c}0.044^{* * *} \\
(0.004)\end{array}$ & $\begin{array}{c}0.044^{* * *} \\
(0.004)\end{array}$ \\
\hline$\Delta$ Balance & $\begin{array}{l}0.0004 \\
(0.014)\end{array}$ & $\begin{array}{c}0.017 \\
(0.015)\end{array}$ & $\begin{array}{c}0.016 \\
(0.015)\end{array}$ & & & \\
\hline$\Delta$ Balance*Partisanship (Categorical) & $\begin{array}{l}0.031^{* *} \\
(0.013)\end{array}$ & $\begin{array}{c}0.060^{* * *} \\
(0.017)\end{array}$ & $\begin{array}{c}0.062^{* * *} \\
(0.017)\end{array}$ & & & \\
\hline$\triangle \mathrm{CAPB}$ & & & & $\begin{array}{c}0.075^{* * *} \\
(0.017)\end{array}$ & $\begin{array}{c}0.075^{* * *} \\
(0.017)\end{array}$ & $\begin{array}{c}0.081^{* * *} \\
(0.018)\end{array}$ \\
\hline$\Delta$ CAPB*Partisanship (Categorical) & & & & $\begin{array}{c}0.064^{* * *} \\
(0.019)\end{array}$ & $\begin{array}{l}0.047^{* *} \\
(0.019)\end{array}$ & $\begin{array}{l}0.048^{* *} \\
(0.019)\end{array}$ \\
\hline Partisanship (Categorical) & $\begin{array}{c}-0.251^{* * *} \\
(0.039)\end{array}$ & $\begin{array}{c}-0.278^{* * *} \\
(0.040)\end{array}$ & $\begin{array}{c}-0.279^{* * *} \\
(0.040)\end{array}$ & $\begin{array}{c}-0.260^{* * *} \\
(0.044)\end{array}$ & $\begin{array}{c}-0.250^{* * *} \\
(0.043)\end{array}$ & $\begin{array}{c}-0.253^{* * *} \\
(0.043)\end{array}$ \\
\hline Log Population & & $\begin{array}{c}5.266^{* * *} \\
(0.470)\end{array}$ & $\begin{array}{c}4.820^{* * *} \\
(0.621)\end{array}$ & & $\begin{array}{c}9.115^{* * *} \\
(0.678)\end{array}$ & $\begin{array}{c}7.847^{* * *} \\
(0.866)\end{array}$ \\
\hline$\Delta$ Growth & & $\begin{array}{c}0.001 \\
(0.010)\end{array}$ & $\begin{array}{l}-0.003 \\
(0.010)\end{array}$ & & $\begin{array}{c}0.040^{* * *} \\
(0.013)\end{array}$ & $\begin{array}{c}0.040^{* * *} \\
(0.013)\end{array}$ \\
\hline$\Delta$ Unemployment & & $\begin{array}{c}0.230^{* * *} \\
(0.022)\end{array}$ & $\begin{array}{c}0.236^{* * *} \\
(0.022)\end{array}$ & & $\begin{array}{c}0.134^{* * *} \\
(0.025)\end{array}$ & $\begin{array}{c}0.134^{* * *} \\
(0.026)\end{array}$ \\
\hline$\Delta$ Inflation & & $\begin{array}{l}-0.003 \\
(0.005)\end{array}$ & $\begin{array}{l}-0.002 \\
(0.005)\end{array}$ & & $\begin{array}{c}-0.107^{* * *} \\
(0.021)\end{array}$ & $\begin{array}{c}-0.114^{* * *} \\
(0.021)\end{array}$ \\
\hline Polity 2 & & & $\begin{array}{c}0.060 \\
(0.040)\end{array}$ & & & $\begin{array}{l}-0.093 \\
(0.136)\end{array}$ \\
\hline Log Phone & & & $\begin{array}{c}0.073 \\
(0.064)\end{array}$ & & & $\begin{array}{l}0.144^{*} \\
(0.085)\end{array}$ \\
\hline Country FE & Yes & Yes & Yes & Yes & Yes & Yes \\
\hline Year FE & Yes & Yes & Yes & Yes & Yes & Yes \\
\hline Log Likelihood & -1660.3 & -1274.23 & -1255.9 & -1138.47 & -976.84 & -962.43 \\
\hline $\mathrm{N}$ & 1066 & 886 & 848 & 726 & 723 & 693 \\
\hline
\end{tabular}


Table A.3: Result of Poisson Regressions with Continuous Partisan Variable

\begin{tabular}{|c|c|c|c|c|c|c|}
\hline & \multicolumn{6}{|c|}{ Dependent variable: } \\
\hline & \multicolumn{6}{|c|}{ Anti-government Movements } \\
\hline & $(1)$ & $(2)$ & $(3)$ & $(4)$ & $(5)$ & $(6)$ \\
\hline Lagged DV & $\begin{array}{c}0.073^{* * *} \\
(0.003)\end{array}$ & $\begin{array}{c}0.060^{* * *} \\
(0.003)\end{array}$ & $\begin{array}{c}0.063^{* * *} \\
(0.004)\end{array}$ & $\begin{array}{c}0.067^{* * *} \\
(0.004)\end{array}$ & $\begin{array}{c}0.046^{* * *} \\
(0.004)\end{array}$ & $\begin{array}{c}0.046^{* * *} \\
(0.004)\end{array}$ \\
\hline$\Delta$ Balance & $\begin{array}{c}0.128^{* * *} \\
(0.037)\end{array}$ & $\begin{array}{c}0.357^{* * *} \\
(0.064)\end{array}$ & $\begin{array}{c}0.370^{* * *} \\
(0.065)\end{array}$ & & & \\
\hline$\Delta$ Balance*Partisanship (Continuous) & $\begin{array}{c}0.017^{* * *} \\
(0.006)\end{array}$ & $\begin{array}{c}0.048^{* * *} \\
(0.010)\end{array}$ & $\begin{array}{c}0.050^{* * *} \\
(0.010)\end{array}$ & & & \\
\hline$\triangle \mathrm{CAPB}$ & & & & $\begin{array}{c}0.419^{* * *} \\
(0.066)\end{array}$ & $\begin{array}{c}0.335^{* * *} \\
(0.064)\end{array}$ & $\begin{array}{c}0.342^{* * *} \\
(0.065)\end{array}$ \\
\hline$\Delta$ CAPB*Partisanship (Continuous) & & & & $\begin{array}{c}0.050^{* * *} \\
(0.011)\end{array}$ & $\begin{array}{c}0.037^{* * *} \\
(0.010)\end{array}$ & $\begin{array}{c}0.038^{* * *} \\
(0.010)\end{array}$ \\
\hline Partisanship (Continuous) & $\begin{array}{c}-0.104^{* * *} \\
(0.018)\end{array}$ & $\begin{array}{c}-0.132^{* * *} \\
(0.020)\end{array}$ & $\begin{array}{c}-0.134^{* * *} \\
(0.020)\end{array}$ & $\begin{array}{c}-0.132^{* * *} \\
(0.022)\end{array}$ & $\begin{array}{c}-0.112^{* * *} \\
(0.022)\end{array}$ & $\begin{array}{c}-0.116^{* * *} \\
(0.022)\end{array}$ \\
\hline Log Population & & $\begin{array}{c}5.294^{* * *} \\
(0.467)\end{array}$ & $\begin{array}{c}4.875^{* * *} \\
(0.624)\end{array}$ & & $\begin{array}{c}8.973^{* * *} \\
(0.679)\end{array}$ & $\begin{array}{c}7.720^{* * *} \\
(0.869)\end{array}$ \\
\hline$\Delta$ Growth & & $\begin{array}{l}-0.001 \\
(0.010)\end{array}$ & $\begin{array}{l}-0.005 \\
(0.010)\end{array}$ & & $\begin{array}{c}0.037^{* * *} \\
(0.013)\end{array}$ & $\begin{array}{c}0.037^{* * *} \\
(0.013)\end{array}$ \\
\hline$\Delta$ Unemployment & & $\begin{array}{c}0.233^{* * *} \\
(0.022)\end{array}$ & $\begin{array}{c}0.241^{* * *} \\
(0.022)\end{array}$ & & $\begin{array}{c}0.124^{* * *} \\
(0.026)\end{array}$ & $\begin{array}{c}0.124^{* * *} \\
(0.026)\end{array}$ \\
\hline$\Delta$ Inflation & & $\begin{array}{l}-0.004 \\
(0.005)\end{array}$ & $\begin{array}{l}-0.003 \\
(0.005)\end{array}$ & & $\begin{array}{c}-0.111^{* * *} \\
(0.021)\end{array}$ & $\begin{array}{c}-0.118^{* * *} \\
(0.021)\end{array}$ \\
\hline Polity 2 & & & $\begin{array}{l}0.069^{*} \\
(0.040)\end{array}$ & & & $\begin{array}{l}-0.085 \\
(0.137)\end{array}$ \\
\hline Log Phone & & & $\begin{array}{c}0.073 \\
(0.065)\end{array}$ & & & $\begin{array}{l}0.143^{*} \\
(0.085)\end{array}$ \\
\hline Country FE & Yes & Yes & Yes & Yes & Yes & Yes \\
\hline Year FE & Yes & Yes & Yes & Yes & Yes & Yes \\
\hline Log Likelihood & -1665.3 & -1271.82 & -1252.85 & -1135.53 & -978.59 & -963.9 \\
\hline $\mathrm{N}$ & 1066 & 886 & 848 & 726 & 723 & 693 \\
\hline
\end{tabular}


Table A.4: Result of Negative Binomial Regressions Considering Period Effects

\begin{tabular}{|c|c|c|c|c|c|c|c|c|}
\hline & \multicolumn{8}{|c|}{ Dependent variable: } \\
\hline & \multicolumn{8}{|c|}{ Anti-government Movements } \\
\hline & Overall & $1980-2015$ & 1990-2015 & $2000-2015$ & Overall & $1980-2015$ & 1990-2015 & 2000-2015 \\
\hline & $(1)$ & $(2)$ & (3) & (4) & $(5)$ & (6) & $(7)$ & $(8)$ \\
\hline Lagged DV & $\begin{array}{c}0.065^{* * *} \\
(0.007)\end{array}$ & $\begin{array}{c}0.063^{* * *} \\
(0.007)\end{array}$ & $\begin{array}{c}0.063^{* * *} \\
(0.008)\end{array}$ & $\begin{array}{c}0.052^{* * *} \\
(0.009)\end{array}$ & $\begin{array}{c}0.059^{* * *} \\
(0.007)\end{array}$ & $\begin{array}{c}0.059^{* * *} \\
(0.008)\end{array}$ & $\begin{array}{c}0.062^{* * *} \\
(0.008)\end{array}$ & $\begin{array}{c}0.055^{* * *} \\
(0.009)\end{array}$ \\
\hline$\Delta$ Balance & $\begin{array}{l}-0.012 \\
(0.034)\end{array}$ & $\begin{array}{l}-0.004 \\
(0.035)\end{array}$ & $\begin{array}{l}-0.004 \\
(0.037)\end{array}$ & $\begin{array}{c}0.013 \\
(0.039)\end{array}$ & & & & \\
\hline$\Delta$ Balance*Partisanship (Categorical) & $\begin{array}{l}0.066^{* *} \\
(0.033)\end{array}$ & $\begin{array}{l}0.061^{*} \\
(0.034)\end{array}$ & $\begin{array}{l}0.064^{*} \\
(0.035)\end{array}$ & $\begin{array}{l}0.078^{* *} \\
(0.038)\end{array}$ & & & & \\
\hline$\triangle \mathrm{CAPB}$ & & & & & $\begin{array}{c}0.046 \\
(0.041)\end{array}$ & $\begin{array}{c}0.046 \\
(0.041)\end{array}$ & $\begin{array}{c}0.044 \\
(0.041)\end{array}$ & $\begin{array}{c}0.052 \\
(0.043)\end{array}$ \\
\hline$\Delta$ CAPB*Partisanship (Categorical) & & & & & $\begin{array}{l}0.064^{*} \\
(0.039)\end{array}$ & $\begin{array}{l}0.065^{*} \\
(0.039)\end{array}$ & $\begin{array}{c}0.064 \\
(0.040)\end{array}$ & $\begin{array}{c}0.058 \\
(0.044)\end{array}$ \\
\hline Partisanship (Categorical) & $\begin{array}{c}-0.211^{* * *} \\
(0.072)\end{array}$ & $\begin{array}{c}-0.206^{* * *} \\
(0.076)\end{array}$ & $\begin{array}{c}-0.211^{* *} \\
(0.083)\end{array}$ & $\begin{array}{c}-0.206^{* *} \\
(0.098)\end{array}$ & $\begin{array}{c}-0.169^{* *} \\
(0.075)\end{array}$ & $\begin{array}{c}-0.172^{* *} \\
(0.077)\end{array}$ & $\begin{array}{c}-0.188^{* *} \\
(0.082)\end{array}$ & $\begin{array}{c}-0.253^{* *} \\
(0.103)\end{array}$ \\
\hline Log Population & $\begin{array}{l}0.205^{* *} \\
(0.103)\end{array}$ & $\begin{array}{l}0.230^{* *} \\
(0.109)\end{array}$ & $\begin{array}{c}0.184 \\
(0.118)\end{array}$ & $\begin{array}{c}0.064 \\
(0.139)\end{array}$ & $\begin{array}{c}0.421^{* * *} \\
(0.121)\end{array}$ & $\begin{array}{c}0.404^{* * *} \\
(0.122)\end{array}$ & $\begin{array}{c}0.358^{* * *} \\
(0.126)\end{array}$ & $\begin{array}{c}0.168 \\
(0.155)\end{array}$ \\
\hline$\Delta$ Growth & $\begin{array}{l}-0.004 \\
(0.019)\end{array}$ & $\begin{array}{c}0.005 \\
(0.020)\end{array}$ & $\begin{array}{c}0.007 \\
(0.021)\end{array}$ & $\begin{array}{c}0.009 \\
(0.023)\end{array}$ & $\begin{array}{c}0.013 \\
(0.024)\end{array}$ & $\begin{array}{c}0.016 \\
(0.024)\end{array}$ & $\begin{array}{c}0.019 \\
(0.025)\end{array}$ & $\begin{array}{c}0.027 \\
(0.025)\end{array}$ \\
\hline$\Delta$ Unemployment & $\begin{array}{c}0.150^{* * *} \\
(0.046)\end{array}$ & $\begin{array}{c}0.157^{* * *} \\
(0.047)\end{array}$ & $\begin{array}{c}0.133^{* * *} \\
(0.051)\end{array}$ & $\begin{array}{c}0.036 \\
(0.061)\end{array}$ & $\begin{array}{c}0.083 \\
(0.053)\end{array}$ & $\begin{array}{c}0.085 \\
(0.054)\end{array}$ & $\begin{array}{c}0.086 \\
(0.057)\end{array}$ & $\begin{array}{c}0.036 \\
(0.066)\end{array}$ \\
\hline$\Delta$ Inflation & $\begin{array}{l}-0.002 \\
(0.009)\end{array}$ & $\begin{array}{l}-0.005 \\
(0.011)\end{array}$ & $\begin{array}{l}-0.004 \\
(0.013)\end{array}$ & $\begin{array}{c}-0.122^{* * *} \\
(0.046)\end{array}$ & $\begin{array}{c}-0.090^{* * *} \\
(0.035)\end{array}$ & $\begin{array}{c}-0.091^{* *} \\
(0.039)\end{array}$ & $\begin{array}{c}-0.077^{*} \\
(0.042)\end{array}$ & $\begin{array}{c}-0.124^{* * *} \\
(0.047)\end{array}$ \\
\hline Polity 2 & $\begin{array}{c}-0.104^{*} \\
(0.061)\end{array}$ & $\begin{array}{c}-0.109^{*} \\
(0.061)\end{array}$ & $\begin{array}{c}-0.116^{*} \\
(0.063)\end{array}$ & $\begin{array}{c}-0.208^{* * *} \\
(0.080)\end{array}$ & $\begin{array}{c}-0.479^{* * *} \\
(0.122)\end{array}$ & $\begin{array}{c}-0.477^{* * *} \\
(0.122)\end{array}$ & $\begin{array}{c}-0.470^{* * *} \\
(0.124)\end{array}$ & $\begin{array}{c}-0.577^{* * *} \\
(0.168)\end{array}$ \\
\hline Log Phone & $\begin{array}{c}0.283^{* * *} \\
(0.092)\end{array}$ & $\begin{array}{c}0.429^{* * *} \\
(0.109)\end{array}$ & $\begin{array}{c}0.588^{* * *} \\
(0.159)\end{array}$ & $\begin{array}{c}3.263^{* * *} \\
(0.620)\end{array}$ & $\begin{array}{c}0.359^{* * *} \\
(0.126)\end{array}$ & $\begin{array}{c}0.371^{* * *} \\
(0.130)\end{array}$ & $\begin{array}{c}0.488^{* * *} \\
(0.164)\end{array}$ & $\begin{array}{c}2.934^{* * *} \\
(0.710)\end{array}$ \\
\hline Constant & $\begin{array}{c}-6.463^{* * *} \\
(2.116)\end{array}$ & $\begin{array}{c}-8.588^{* * *} \\
(2.364)\end{array}$ & $\begin{array}{c}-9.659^{* * *} \\
(2.846)\end{array}$ & $\begin{array}{c}-38.654^{* * *} \\
(7.651)\end{array}$ & $\begin{array}{c}-7.411^{* * *} \\
(2.672)\end{array}$ & $\begin{array}{c}-7.286^{* * *} \\
(2.703)\end{array}$ & $\begin{array}{c}-7.984^{* * *} \\
(2.982)\end{array}$ & $\begin{array}{c}-32.881^{* * *} \\
(8.604)\end{array}$ \\
\hline Country FE & Yes & Yes & Yes & Yes & Yes & Yes & Yes & Yes \\
\hline Year FE & Yes & Yes & Yes & Yes & Yes & Yes & Yes & Yes \\
\hline Log-Likelihood & -894.61 & -794.04 & -669.42 & -479.32 & -725.77 & -705.74 & -616.49 & -422.94 \\
\hline $\mathrm{N}$ & 848 & 766 & 634 & 438 & 693 & 679 & 597 & 397 \\
\hline
\end{tabular}

